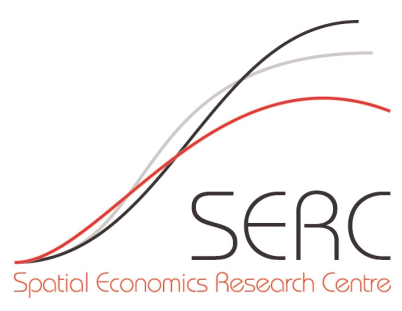

SERC DISCUSSION PAPER 2

\title{
Models of Regional Growth: Past, Present and Future
}

Richard Harris (SERC, CPPR and University of Glasgow)

July 2008 
This work was part of the research programme of the independent UK Spatial Economics Research Centre funded by the Economic and Social Research Council (ESRC), Department for Business, Enterprise and Regulatory Reform (BERR), the Department for Communities and Local Government (CLG), and the Welsh Assembly Government. The support of the funders is acknowledged. The views expressed are those of the authors and do not represent the views of the funders.

(c) Richard Harris, submitted 2008 


\title{
Models of Regional Growth: Past, Present and Future
}

\author{
By \\ Richard Harris (SERC, CPPR \& University of Glasgow)
}

May 2008

* An earlier version of this paper was presented at Urban and Regional Economics Seminar Group Seminar Meeting: 10-11 January 2008, University of Glasgow. My thanks to participants for comments and suggestions; however, responsibility for the paper rests solely with the author. 


\section{Introduction}

This paper presents an overview of various models of regional growth that have appeared in the literature in the last 40 years. It considers the past, and therefore supply-side models, such as the standard neoclassical, juxtaposed against essentially demand-side approaches such as the export-base and cumulative causation models (as integrated into the Kaldorian approach); before moving on to the present and more recent versions of the neoclassical model involving spatial weights and 'convergence clubs', as well as New Economic Geography core-periphery models, and the 'innovation systems' approach. A key feature of the more recent literature is an attempt to explicitly include spatial factors into the model, and thus there is a renewed emphasis on agglomeration economies and spillovers. Discussing 'present' and 'future' approaches to regional growth overlaps with the current emphasis in the literature on the importance of more intangible factors such as the role of 'knowledge' and its influence on growth. Lastly, there is a discussion of the greater emphasis that needs to be placed at the 'micro-level' when considering what drives growth, and thus factors such as inter alia firm heterogeneity, entrepreneurship, and absorptive capacity.

Of major importance in any discussion of growth at the spatial (or indeed any) level is the search for the key long-run drivers of growth, and where possible identifying those determinants that are exogenous at a regional level and are thus amenable to policy intervention. That is, it is important to know what ultimately determines growth and therefore where policy-makers should concentrate their efforts to improve economic development, while at the same time avoiding the Lucas Critique whereby the very act of invoking a particular policy changes the underlying relationships between the variables in the model, thus tending to make policy at best difficult to evaluate in terms of any positive impacts, and at worst ineffective (and possibly detrimental in terms of the long-run impact on say output levels). ${ }^{1}$ Thus, even if it is difficult to identify which key variables are exogenous - mostly because of data limitations - it is still an important aim to establish (causal) linkages between variables for both policy purposes and to understand the processes underlying growth.

As will become apparent, more recently there has been an emphasis in the extant literature on the micro-aspects of spatial economic growth - as Cheshire and Malecki (2004) state: “... the ultimate actors are not regions but households, establishments and firms and how these interact" (p.250). This move away from aggregate models of growth has at least two important implications: (i) in principle what we mean by a region is defined in terms of maximising intra-regional activities that crucially determine long-run growth (such as knowledge spillovers, labour market characteristics, and other agglomeration effects) and minimising inter-regional activities, even though these are also significant determinants (see van Stel and Nieuwenhuijsen, 2004); and (ii) there emerges a mostly empirical issue about the size and thus importance of external spillovers available to economic agents vis-à-vis the importance of internal factors that determine productivity and growth at the microlevel. With respect to (i), empirical work still faces the problem of defining the appropriate unit of analysis, where again data limitations play an important role in what is practically possible and what is not. Although some micro-data bases have very disaggregated geographic codes, other relevant data is still only available at predefined (aggregated) spatial units. Concerning the relative importance of external 
spillovers, this is particularly important for policy; limited resources require choices about whether policy should be aimed directly at economic agents or whether it should concentrate on trying to improve the infrastructure and environment in which agents interact. For example, if the outputs from R\&D are largely non-appropriable (and thus spillover to other firms) then government policy should aim at improving R\&D cooperation, networks, university-firm linkages, etc. If, however, the benefits of R\&D are mostly firm specific (and if the external influences on the determinants of R\&D spending are mainly through specific firm-to-firm pecuniary linkages), then policy to increase R\&D should be focused on helping firms directly rather than the external environment in which firms operate (see Vega-Jurado et. al., 2008, where internal factors were found to be more important in determining product innovation in Spanish firms).

It is also important to consider whether - as Richardson (1973) put it - regional growth is 'competitive' or 'generative'. In the former, where the growth of the national economy is assumed given and regional growth is just a zero-sum allocation and distribution of production, the outcome is "... the growth of one region is always at the expense of another" (Richardson, 1978, p. 145). Neoclassical and other spaceless regional growth models (e.g. Harrod-Domar) usually fall into this 'competitive' category, and indeed this still seems to influence HM Treasury thinking on what determines growth in the UK. In contrast, 'generative' models treat national growth as the outcome of the growth rates of the regions comprising the economy; thus national growth can be higher if regional growth rates improve and "agglomeration economies and spatial clustering of activities may induce more output than if production is dispersed... and additional growth may come from improvements in spatial efficiency rather than from additional factor inputs" (Richardson, 1978, p.146). Clearly, more recent models and approaches to regional growth are generally of the 'generative' type, and therefore they imply "... that regional and urban economic analysis must be spatial" (Richardson, op. cit., p. 147).

\section{The Past...}

\section{(a) Neoclassical growth model}

This model shows the determinants of growth from the supply-side, since taking a (logged) homogenous Cobb-Douglas aggregate production function with constant returns-to-scale, and totally differentiating with respect to time gives:

$$
\frac{\Delta \mathrm{Y}}{\mathrm{Y}}=\frac{\Delta \mathrm{A}}{\mathrm{A}}+\alpha \frac{\Delta \mathrm{K}}{\mathrm{K}}+(1-\alpha) \frac{\Delta \mathrm{L}}{\mathrm{L}}
$$

Hence, the reasons why regional growth disparities can occur are:

(1) technology (A) may vary between regions;

(2) growth of the capital stock (K) may vary between regions;

(3) growth of the labour force (L) may vary between regions.

The standard approach makes some basic, and rather tenuous, assumptions on how the economy works: (i) there is perfect competition in all markets so that factors of production (labour and capital) are paid equal to their marginal products; price is 
fixed for any firm; factors of production are completely mobile across regions and will migrate/move to obtain the highest returns; there is perfect flexibility of factor prices so that interregional movements of capital and labour will automatically remove factor price differences between regions; and there is instantaneous diffusion of new (disembodied) knowledge (innovations) throughout the economy so that all firms have access to the latest technology. Thus distance does not play any role in the model.

Assuming capital and labour are mobile, the neoclassical model shows that there can be no systematic long-run differences in the growth rate of factors across regions. Thus, it is likely that differences in total factor productivity levels ${ }^{2}$ are the most important source of any long-run growth differences (even though this is inconsistent with the assumptions underlying the approach). However, if technological change is at least partly determined by an endogenous process (e.g. it depends on levels of knowledge), then the ability of a region to benefit from technological change through diffusion may be much slower if there are interregional differences in knowledge stocks. This has lead to the development of 'technology-gap' models where regions that lag furthest behind the technology level of the most advanced region are presumed to experience the fastest rate of 'catch-up' and thus the fastest rate of growth in TFP. In terms of equation (1) this supposes the following change in technology for region $r$ :

$$
\frac{\Delta A_{r}}{A_{r}}=\lambda\left(A^{*}-A_{r}\right) \quad \lambda>0
$$

where $A^{*}$ is the technology level in the most advanced region. This approach has evolved from the literature on trade and growth, and the role that $R \& D$ and technology transfer plays in allowing lagging countries to 'catch-up' with technological leaders (e.g. the U.S.). 'Technology-gap' models suggest, firstly, that differences in TFP are likely to be the main driver of persistent regional growth disparities; secondly, that leading regions have higher TFP because of their greater stock of knowledge and human capital; and, thirdly, that much of the technological development that occurs in lagging regions is through diffusion of existing technology rather than the development of new products and processes. ${ }^{3}$ Hence, the following conclusion is generally reached (Armstrong and Taylor, 2000, p. 87):

“... the primary reason for long-term persistence is that some regions are more able to generate their own technical change. Knowledge-rich regions with an institutional environment conducive to the creation and transmission of new ideas will have a continuing advantage over less well-endowed regions which depend far more on acquiring technical change through purchasing capital equipment from other regions. Less well-endowed regions have no alternative but to rely on exogenously embodied technology since they are not capable of producing their own."

In terms of testing for neoclassical convergence, the derivation of the empirical model invariably used has been set out in various texts (e.g. Barro and Sala-i-Martin, 1995); the result is the following cross-sectional model for estimation:

$$
\ln \frac{y_{T, i}}{y_{0, i}}=\alpha+\beta \ln y_{0, i}+\varepsilon_{i}
$$


where $y_{T, i}$ typically refers to GDP per capita in time $T$ in region $i ; y_{0, i}$ refers to GDP per capita in time 0 in region $i ; \beta$ (assumed to be negative) can be used to measure the speed-of-convergence to the stead-state (equilibrium) rate of growth that all regions are presumed to converge upon in the long-run. ${ }^{4}$ Thus, initially regions with lower levels of GDP per capita are presumed to 'catch-up' (i.e. converge) on those with higher GDP per capita, implying that regions with initially lower values of $y_{0, i}$ grow faster. ${ }^{5}$

Statistically, we can test the null hypothesis $(\beta=0)$ against the alternative $(\beta<0)$, and if we reject the null then poor regions grow faster than rich ones, and all regions converge to the same level of per capita income. Acceptance of the null is often taken as evidence in favour of the neoclassical growth model, but as shown by Roberts (2007) it is possible to derive similar (conditional) convergence models using a Kaldorian framework, such that any finding of (conditional) convergence does not necessarily discriminate in favour of any particular theory of regional growth.

There are a number of problems with using equation (3) to test for convergence (see also Cheshire and Malecki, 2004, section 2). Inter alia, these include:

1. It assumes all regions are converging versus non-convergence; it does not allow some regions not to be converging.

2. Even if all regions are converging, this may not be to a single steady-state value. Different regions may converge towards different equilibrium rates of growth.

3. The $\beta$-convergence model can only test for 'catch-up'; it estimates whether (on average) the distance between regions at the end of a period is less than at the start. Thus the model cannot encompass regions that have achieved a period of steady-state equilibrium whereby observations are moving together over time without any further narrowing (or broadening) of the gap between them.

4. The model ignores any spillovers between regions, leading to spatial dependence, and thus is incorrectly specified. Consequently estimates of $\hat{\beta}$ are likely to be biased.

Recent developments in empirically estimating the $\beta$-convergence model have gone some way to overcoming issues (1) and (2) - through allowing for spatial heterogeneity and explicitly testing for 'convergence clubs'; while allowing for spatial dependence has resulted in the use of spatial econometric models. Both spatial heterogeneity and dependence are discussed below. The third issue above is essentially the result of using a cross-sectional approach to measuring convergence. An alternative approach (Harris and Trainor, 1999) is not to use just the start and end values of GDP per capita but to use a time series of observations covering the whole period from 0 to $T$; and then to test whether there is convergence between region $j$ and the region with the highest GDP per capita (assumed in the UK to be the SE region). Essentially, the following model can be estimated:

$$
\Delta\left(y_{i, j}-y_{i, S E}\right)_{t}=\varphi\left(y_{i, j}-y_{i, S E}\right)_{t-1}+\mu+\gamma+\varepsilon_{t}
$$

where $\left(y_{i, j}-y_{i, S E}\right)$ measures the gap in log GDP per capita between the region $j$ and the 'best' region in time period $t$ or $t-1 ; \Delta$ measures the change in the variable 
between time period $t$ or $t-1 ; \mu$ is just the intercept in the regression; and $t$ represents a time trend (so the parameter $\gamma$ measures whether the dependent variable is trending upwards or downwards over time). If the null hypothesis $\varphi=0$ is accepted, then the two series, $y_{i, j}$ and $y_{i, S E}$ are in disequilibrium with regard to each other and will drift apart over time. If $\varphi<0$, there is an equilibrium relationship between the two series which can take on three forms:

- If $\gamma>0$. there is 'catching-up';

- If $\gamma<0$, there is equilibrium divergence (i.e. they grow apart);

- If $\gamma=0$, the two series are in long-run equilibrium to each other and they neither move apart or closer together.

However, despite these empirical developments in testing for $\beta$-convergence, perhaps the most important issue with the approach (other than the unrealistic assumptions that underpin the model) is that many studies find little or no evidence for convergence (e.g. with respect to EU regions: Cuadrado-Roura, 2001; Lopez-Bazo et. al., 1999; Magrini, 1999; Puga, 2002; and Rodriguez-Pose, 1999), the results obtained are often significantly influenced by outliers in the data, while typically those that do find convergence provide estimates of no more than $2 \%$ per annum, and therefore half-lives of over 40 years (see Abreu et. al., 2005, for a recent review). ${ }^{6}$ In addition, conditional convergence models typically do not consider causality issues and therefore add little to our understanding as to what factors drive growth and which are amenable to policy interventions, other than the expectation that we should probably concentrate on what determines differences in technologies across regions. In sum, and despite their (continued) popularity, standard neoclassical $\beta$-convergence models are limited in terms of understanding growth differences across the spatial economy.

In short, it can be argued that (Cheshire and Malecki, 2004, p. 251):

“... regional growth is dependent on attracting and keeping capital and labour - to become 'sticky' places (Markusen 1996) - and making them more productive. This process does not necessarily result in a tidy equilibrium growth path, as the neo-classical model assumes... or in convergence of growth rates. Instead, shocks, disequilibrium and divergent growth remain recurrent features of the real world"

\section{(b) Kaldorian models}

Elements of the 'cumulative causation' models that date from Myrdal (1957) and Hirshmann (1958) were formalised in a regional context by Dixon and Thirlwall (1975), following Kaldor's (1970) more general exposition of the regional growth process. Such models operate under increasing-returns-to-scale with virtuous circles of spread and backwash (feedback) between output and productivity growth (i.e. the Verdoorn relationship). However, it is argued that exogenous demand in the exportbase is the key driver of regional output (based on Harrod's foreign-trade multiplier approach). In addition, such Kaldorian models result in a growth rate that is not necessarily convergent in the sense that all regions end up with the same growth rate; in fact the approach is more likely to lead to divergent (and even disequilibrium) growth paths between regions. 
The Kaldor-Dixon-Thirlwall (hereafter KDT) model has been extended by Thirlwall (1980) to allow for a balance-of-payments constraint (hence adopting Harrod's dynamic foreign-trade multiplier approach); while relative price effects are often assumed to be unimportant, and thus the competitiveness of the export-base is linked to (non-price) quality improvements brought about by increases in productivity rather than by terms-of-trade price differences. It is this extended model that is presented here.

Firstly, we define the export- and import-demand functions (assuming no changes in the relative prices of exports and imports ${ }^{7}$ ) as:

$$
\begin{aligned}
\dot{M} & =\pi(\dot{Y}) \\
\dot{X} & =\varepsilon(\overline{\dot{Z}})
\end{aligned}
$$

where $M$ and $X$ denote imports and exports (in real terms), respectively; $Y$ denotes real GDP; $Z$ is the level of 'world' income; and $\pi$ and $\varepsilon$ are the income elasticities of the demand for imports and exports, respectively. Note, a 'dot' over a variable specifies that the variable has been differentiated with respect to time ${ }^{8}$, while a 'bar' denotes that it is taken to be exogenous to the region. Secondly, the balance-of-payments (in real terms) is given as: ${ }^{9}$

$$
\dot{M}=\dot{X}
$$

Equation (7) implies that in the long-run, the region cannot run a balance-of-trade deficit hence long-run regional import growth can only be sustained by the growth of regional exports. Substituting equations (5) - (6) into (7) and rearranging gives the dynamic Harrod trade multiplier:

$$
\dot{Y}=\frac{\varepsilon \dot{Z}}{\pi}=\frac{\dot{X}}{\pi}
$$

Equation (8) says that the balance-of-payments constrained long-run growth rate of the region is equal to the long-run rate of growth of exports divided by the regional income elasticity of demand for imports.

Turning to the supply-side, the Verdoorn relationship is derived from the production function. Following McCombie (1988), we start with a Cobb-Douglas (dynamic) production function (viz. equation 1):

$$
\dot{Y}=\dot{A}+\alpha \dot{K}+\beta \dot{L}
$$

where $\alpha$ and $\beta$ are the output elasticities of capital and labour (with $\alpha+\beta=v>1$ ). We can divide through in equation (9) by labour and obtain an expression for labour productivity as:

$$
\dot{\rho}=\frac{\dot{A}}{v}+\left(\frac{v-1}{v}\right) \dot{Y}+\frac{\alpha}{v}(\dot{K}-\dot{L})
$$

However (i) the growth of the capital-labour ratio is not an independent determinant of labour productivity; it is a function of the growth of output. Hence $(\dot{K}-\dot{L}=\omega \dot{Y})$. Similarly, (ii) technical progress is at least in part endogenous through 'learning-bydoing' effects that are associated with higher levels of output (e.g. R\&D spending is positively associated with size). Hence $\left(\dot{A}=\overline{\dot{A}}^{\prime}+\varsigma \dot{Y}\right)$. Substituting for endogenous growth in the capital-labour ratio and endogenous technical change gives: 


$$
\dot{\rho}=\left(\overline{\dot{A}}^{\prime} / v\right)+\frac{(v-1+\alpha \omega+\varsigma)}{v} \dot{Y} \quad \text { or } \quad \dot{\rho}=\overline{\dot{a}}+b \dot{Y}
$$

That is, labour productivity growth is determined by autonomous technological change, $\overline{\dot{a}}$; and the Verdoorn coefficient $(\mathrm{b}>0)$ is determined by: (i) increasing returns-to-scale ( $v$ must be greater than 1 in equation 11); (ii) the growth in the capital-labour ratio, via $\omega$; and (iii) endogenous technological change, via $\zeta$.

Finally, to 'close' the model, it is presumed that increases in labour productivity will result in real quality improvements in the production of export goods (rather than lower product prices as featured in the original KDT formulation), and this results in a higher demand for regional exports through a higher income elasticity of demand, $\varepsilon$. That is, rather than physical productivity (through efficiency gains) being the main link to the growth of exports, it will be the quality of differentiated goods and services that secure higher volumes of sales (and/or higher revenue productivity). ${ }^{10}$ Quality and differentiation of goods is more likely where firms are innovators (cf equation 11). Thus, we now treat $\varepsilon$ as varying (rather than fixed) and thus endogenous. E.g.:

$$
\varepsilon=\theta \dot{\rho}
$$

Figure 1: Steady-state regional growth

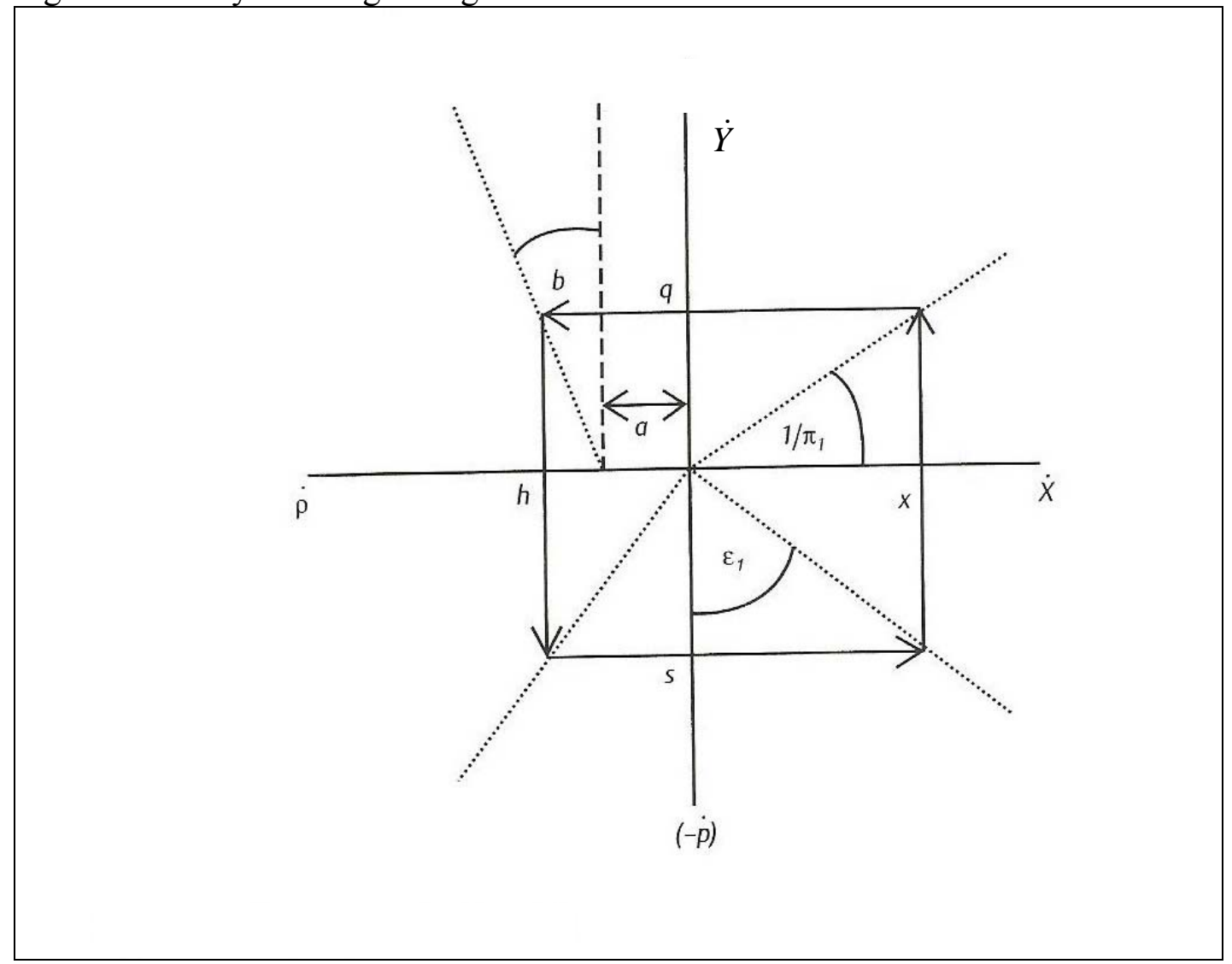

Source: McCann (2001, Figure 6.12)

Figure 1 (based on McCann, 2001, Figure 6.12) shows steady-state regional growth based on the above version of the KDT model. Given export growth of $x$, and an income elasticity of demand for imports of $\pi_{1}$, the balance-of-payments constrained 
growth of output is $q$ (upper right-hand quadrant). Via the Verdoorn effect, output growth of $q$ results in regional labour productivity growth of $h$ (the larger are either $a$ or $b$, the larger the impact of $\dot{Y}$ on $\dot{\rho}$ ). And for given (relative) output prices, productivity growth $h$ results in real quality improvements, which in turn result in regional export growth of $x$ (with the strength of export growth dependent on the income elasticity of demand for the region's exports, $\varepsilon_{1}$ ). In Figure 1, the relationship between $\dot{X}$ and $\dot{Y}$ is a steady-state (equilibrium) relationship. ${ }^{11}$ However, different regions can have different growth rates, dependent in particular on the ratios of the income elasticities of demand for the region's exports and for its imports (see equation 8).

Figure 2: Cumulative regional growth

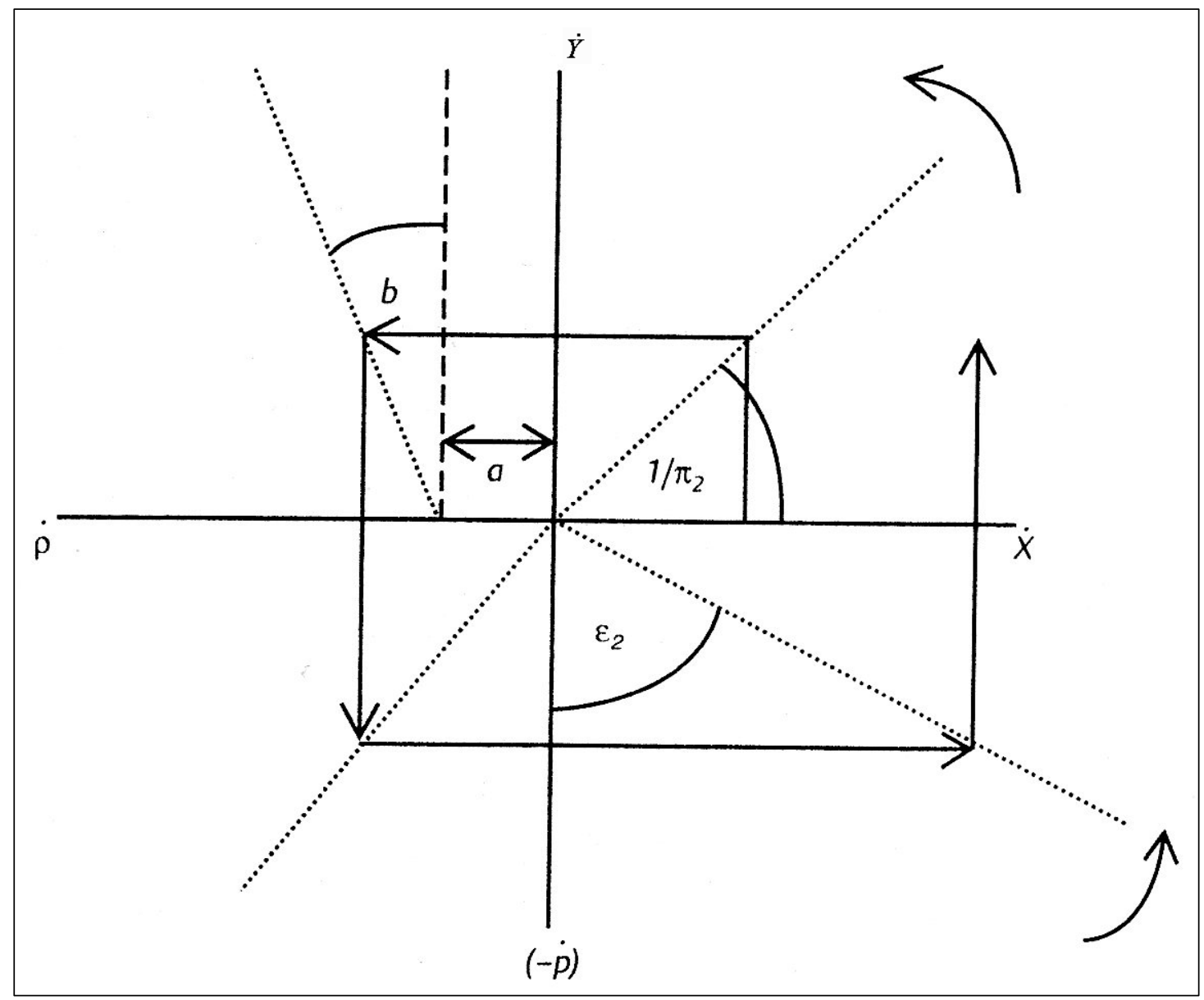

Source: McCann (2001, Figure 6.13)

However, it is possible (and perhaps more likely) for this model to produce disequilibrium growth. Cumulative growth is set out in Figure 2; in this situation McCann (2001) argues that the region may be characterised by a dense clustering of industries which exhibit agglomeration economies that lead to: (i) the purchase of large quantities of its input requirements from within the local regional economy; and (ii) higher levels of innovation outputs (through knowledge spillovers). The first leads to a lower regional income elasticity of demand for imports $\left(\pi_{2}<\pi_{1}\right)$; while (ii) leads to a higher income elasticity of demand for exports $\left(\varepsilon_{2}>\varepsilon_{1}\right)$. This combination of a higher income-elastic demand for exports and a low income elastic demand for 
imports, and the role played by the Verdoorn relationship (cumulative causation due to increasing returns-to-scale and endogenous technological growth), leads to cumulative growth. In comparison, if a region is dominated by firms producing relatively low income-elasticity exports (e.g. standardised 'mature' products), and at the same time being relatively dependent on imports (e.g. a peripheral region having suffered severe industrial decline and then subsequent employment growth in 'footloose' FDI firms), the result is cumulative decline (see McCann, 2001, Figure 6.14).

The KDT model as discussed here is based on less restrictive assumptions when compared to the neoclassical model (e.g. it does not require factors to be paid their marginal products and thus relaxes the assumption of perfect competition; it does not require constant returns-to-scale, but rather the more likely increasing returns; and it does not imply a single long-run growth rate to which all regions will converge).

And while this model emphasises the key role of the growth of exogenous demand as ultimately driving output growth and productivity, this is not to the exclusion of the supply-side. As with any theory, ultimately whether the demand- or supply-side dominates - if indeed one-side does dominate - is an empirical matter. Moreover, while the demand for exports plays a key important role, it is shown above that the values of certain supply-side parameters (possibly associated with agglomeration economies and knowledge spillovers) are important for determining which regions are likely to experience increasing growth rates and which do not.

However, the KDT model also has certain drawbacks, such as interregional feedbacks (i.e. spatial dependence) and spillovers are not explicitly included; ${ }^{12}$ with regard to spillovers, the explanation by McCann for Figure 2 could be replaced by assuming that (i) the purchase of large quantities of input requirements from within the local regional economy is mainly the result of pecuniary transactions internal to the firms involved - i.e. they do not involve non-appropriable spillovers that all firms benefit from freely; and (ii) higher levels of innovation outputs might similarly be because of higher expenditure on firm-specific $R \& D$ that does not involve any major knowledge spillovers. Because the KDT model does not explicitly model both internal and external factors, it is not possible to differentiate the relative importance of external spillovers. It might be possible to revise the model along these lines, but the result would likely be too complex. Being able to discriminate between complex alternative sources of growth is only likely to be amenable to micro-based models, although these potentially loose out since they usually cannot capture the bigger 'picture' of what determines regional growth.

Finally, it is worth noting that empirical testing of Kaldorian models has generally not been possible due to the lack of trade data at the sub-national level. Generally empirical work at the regional level has confined itself to the testing of the Verdoorn relationship (e.g. McCombie and de Ridder, 1984; Harris and Lau, 1998; McCombie and Roberts, 2007). 


\section{The Present...}

\section{(a) Neoclassical growth model - new estimation techniques}

In discussing $\beta$-convergence, it was noted above that the standard approach to testing does not allow some regions not to be converging; and even if all regions are converging, this may not be to a single steady-state value. Different regions may converge towards different equilibrium rates of growth. The model also ignores any spillovers between regions, leading to spatial dependence, and consequently estimates of $\hat{\beta}$ are likely to be biased.

To overcome the first problem, more recent work has recognised that there may be spatial heterogeneity resulting in 'clubs' or groupings of regions that converge to different long-run growth rates. This is especially the case if regional convergence results in a core-periphery dichotomy (Corrado et. al., 2005). Convergence 'clubs' may also be based on spatial proximity associated with industrial clusters, resulting from spillovers and interfirm demand-supply networks; although this might coincide with the core-periphery outcome. Additionally, urban agglomerations may result in a number of convergence 'clubs' with different long-run steady-state growth rates.

Having recognised the likelihood that there may be convergence 'clubs', the problem then arises of how to identify which regions join each 'club'. The literature has taken a number or routes: from arbitrarily chosen cut off levels of (initial) values of relevant variables; to using spatially weighted test statistics of clustering (e.g. Fischer and Sturbeck, 2006, use the Getis and Ord (1992) $G^{*}(\delta)$-statistic applied to initial values of per capita GDP); and to formally testing using time-series data whether regional per capita GDP 'moves together' over time (and are thus stationary). The first, and most simplest approach, does not involve any formal testing and it can be difficult to distinguish club-convergence from conditional convergence. That is, with conditional convergence the right-hand-side variables in the $\beta$-convergence model may be the same (or significantly correlated) with the variables used to form the 'clubs' (even with the simplest $\beta$-convergence model initial values of the dependent variable enter as a regressor, and this variable is likely to be used to delineate the sub-groups of regions into clubs). In contrast, spatially weighted tests of association are dependent on obtaining spatial weights, and problems associated with this are discussed below.

The more recent use of time-series techniques to test if regional per capita GDP series move together over time involves estimating a similar model as that set out in equation (4), but allowing for all regions $i$ and $j$ to form pairs. This approach has been used by Corrado et. al. (2005), using NUTS1 data for the regions of the EU (covering 1977-1999) separately for 4 industry sub-groups. ${ }^{13}$

Once convergence 'clubs' have been obtained, these can be tested separately for $\beta$ convergence. Generally, the results obtained do not result in significantly different outcomes compared to the standard approach. For example, Fischer and Sturbeck (2006) obtain two 'clubs' using NUTS2 EU data for 1995-2000, finding 2.4\% p.a. convergence in the 'peripheral' regions (comprising mostly Central and Eastern Europe) and $1.6 \%$ p.a. convergence in the 'core' (the other EU regions).

Turning to $\beta$-convergence models that incorporate spatial dependence, these are a (partial) attempt to explicitly incorporate geographic spillovers. Typically, spatial 
dependence is included by weighting the data using a spatial weight matrix that usually has positive elements for 'neighbouring' regions, and zero elements for other pairs of regions. Assuming such a matrix $W$ can be computed, this then allows for three alternative specifications that control for spatial autocorrelation:

$$
\begin{aligned}
& \ln \frac{y_{T, i}}{y_{0, i}}=\alpha+\beta W \ln y_{0, i}+\varepsilon_{i} \\
& \ln \frac{y_{T, i}}{y_{0, i}}=\alpha+\beta \ln y_{0, i}+\rho W \varepsilon_{i}+v_{i}
\end{aligned}
$$

Equation (13) is the spatially lagged dependent variable model (and it assumes spatial autocorrelation follows an autoregressive process). If a conditional $\beta$-convergence model is estimated (thus additional right-hand-side regressors are included in the equation), a second specification would be to assume that spatial autocorrelation can be controlled by pre-multiplying these other regressors (rather than $y_{0}$ ) by $W$. Thirdly, equation (14) assumes that spatial autocorrelation follows a moving-average process and thus the error term $\varepsilon$ is weighted ( $\rho$ is the autocorrelation coefficient to be estimated using a maximum likelihood procedure, while $v$ is an error term with the required Gaussian properties).

The central problem then is to obtain $W$, since the proper specification of the spatial weights matrix is not always obvious As stated above, contiguous regions are typically assigned a value of 1 in $W$, and regions that are distant from each other are assigned a value of 0 . Deciding which regions are deemed to be sufficiently 'close' such that spillovers can occur is not straightforward. Various permutations involving different values of the distance bandwidth can be experimented with, but there is no statistical test of a null hypothesis available as to which bandwidth is optimal. And the results obtained (using equations 13 and 14) can be very sensitive to the construction of $W$. There is also a more general issue that spillovers are assumed to be at their strongest the closer are regions to each other. Spillovers from a region located some distance away are not incorporated into $W$, and yet in the UK context it might be argued that all regions might experience positive and negative spillovers from the South East (e.g. through labour and housing market effects, as well as production externalities, given that many plants operating in peripheral regions are owned and controlled through headquarters located in the South East - see Harris, 1988, and Ashcroft et. al, 1994).

An alternative approach might be to include (dummy) variables representing other regions when modelling growth in region $r$, and then formally testing whether such variables are statistically significant. For example, van Stel and Nieuwenhuijsen (2004) estimate a model using NUTS3 data, but they also tested for the statistical significance of NUTS1 and NUTS2 dummies on the premise that interregional spillovers across NUTS3 areas (if present) can be captured by higher-level regional dummies. They recognised the limitations of their approach ("... distant regions may interact more than neighbours because they contain important cities and are well connected by communications networks" - van Stel and Nieuwenhuijsen, op. cit., p. 400), but did not go further and include dummies in their model for regions located outside the higher-level region, although in principle this would seem an obvious extension of their approach. 
Another approach might be to compute the elements in $W$ using other relevant information than simply distance; for example, Jaffe (1986) attempted to position a firm in its technological and geographic space based on a vector describing the distribution of its patents (or its R\&D spending) across product fields. Thus, the firm is linked specifically to those industries and localities from which it potentially obtained (or supplied) information. ${ }^{14}$ Of course, aggregate studies using regional data (rather than micro-based firm data) would find it difficult to capture such specific knowledge flows. Alternatively, the comparable approach used by Coe and Helpman (1995) in measuring international R\&D spillovers may be more practical. They weighted the R\&D stocks of trade partners by the share in imports, on the assumption that the stronger the links between trade partners the greater the propensity for spillovers. If ancillary data can be obtained which measures the strength of links between regions, then this should provide additional, objective information on how to compute $W$.

Finally, it is worth noting that when spatial autocorrelation is accounted for, using a conventional measure of $\mathrm{W}$, then the results obtained show that 'catch-up' is often significantly slower (e.g. Rey and Montouri, 1999; O Huallachain, 2007; Henley, 2005).

\section{(b) New Economic Geography models}

The development of new trade theory (e.g. Krugman, 1980; Krugman and Venables, 1990) and new economic geography models (e.g. Krugman, 1991; Krugman and Venables, 1995; Baldwin et. al., 2003) has resulted in 'space' being recognised more widely as a crucial factor in determining economic development (with an emphasis in these models on trade flows and industrial location). New Trade Theory (NTT) models assume monopolistic competition, and thus increasing returns-to-scale (whereby firms can produced more cheaply by concentrating production in a smaller number of potentially spatially co-located plants); and product differentiation (reflecting consumers 'love-of-variety'). In addition to economic activities clustering to realise economies-of-scale, they also locate where a large consumer market exists to minimise transportation (and other trade barrier) costs and to have good access to product markets. This means that a region will export goods for which it has a relatively large domestic demand - the so-called 'home market' effect. Note, increasing returns-to-scale are not necessarily technology-based and thus internal to the firm; the concentration/clustering of firms is most likely because of pecuniary externalities of location which are even more important when the consumer market is large (e.g. in the 'core').

The New Economic Geography (NEG) approach extends NTT to produce explanations for the geographic clustering of industries. In the NTT approach, the home-market size is exogenous (determined by the fact that especially labour is presumed to be immobile; clearly capital is allowed some ability to relocate in the NTT model to bring about clustering and exploitation of scale economies to benefit from given home-market effects); while the NEG approach allows the home-market effect to become endogenous, primarily through the mobility of labour, but also through allowing greater mobility of firms which have high levels of intermediate demand. Thus with both firms and labour mobility, there is even greater reallocation of economic activities across regions, with those regions having an initial market size 
advantage finding that falling trade costs and increasing returns-to-scale give rise to a process of cumulative causation.

The variant of the NEG model that concentrates on labour mobility sees additional workers migrating to those regions where clusters have formed, in order to benefit from strong home-market effects. The influx of labour stimulates the home-market effect even further. The variant that concentrates on capital mobility in industries with strong input-output linkages (i.e. strong intermediate demand) works through the impact of the home-market effect of vertical (i.e. backward or demand) linkages and horizontal (i.e. forward or cost-based) linkages: ${ }^{15}$

- in terms of backward linkages, the home-market effect means that upstream firms are drawn to the locations where there are many downstream firms (i.e. where demand is high)

- in addition, there is a cost (or forward) benefit since having a large number of upstream firms in the same location allows downstream firms to obtain their intermediate goods more cheaply (lower transport costs, more intense competition in the upstream industry, greater/better product variety).

These forward and backward linkages create the conditions for the clustering of such intermediate-goods related industries. The greater the proportion of intermediate goods in the production of final goods, the greater are these demand and cost linkages, and the greater the gains from geographical/spatial clustering.

However, there are also centrifugal forces (such as congestion diseconomies especially local housing costs) that will counterbalance the tendency for agglomeration and clustering. Consequently, the NEG model actually has many possible equilibrium outcomes that are sensitive to these counter-prevailing centripetal and centrifugal forces. Thus some NEG models predict a persistent coreperiphery dichotomy (in output levels); others result in differential growth rates and thus divergent paths; while some suggest that there can be initially divergence followed by convergence as centrifugal forces overcome centripetal benefits.

In summary, NEG models have renewed interest in trade (and hence the export-base), agglomeration and cumulative causation as key factors determining regional growth. Concentration/clustering has a positive effect on productivity because of agglomeration economies (leading to firms at such 'core' locations gaining an advantage), and the resultant centralisation of highly innovative, knowledge intensive firms (as well as the high-skilled labour they employ) is expected to perpetuate the economic advantage of the core over the periphery, where standardised, routine production facilities tend to dominate. The end result is sustained differences in regional development at the core and periphery (Baldwin and Martin, 2004). ${ }^{16}$ Because agglomeration economies (first development in the work of Marshall, 1890) play such an important part in NEG models (and indeed in other literature dealing with regional growth), the next section is devoted to a more detailed discussion of types and consequences of agglomeration economies of scale. In a later section we deal with their importance within the context of 'innovation systems'.

\section{(c) Agglomeration economies of scale}

The first type of agglomeration economies is generally labelled localisation externalities and they are attributable to Marshall (1890), Arrow (1962), and Romer 
(1986) - hence the term MAR-spillovers. Such spillovers minimise transport and transaction costs for goods, people, or ideas, and thus to benefit from them suggests that firms within a specific industry locate near other firms along the supply chain (be they customers or suppliers); locate near other firms that use similar labour; and/or locate near other firms that might share knowledge (Ellison, et. al., 2007). MARspillovers are associated with industrial specialisation and are to a large extent an intra-industry phenomenon (where this covers firms belonging to a particular industry, or closely related industries).

Clearly firms locate in close proximity to reduce the costs of purchasing from suppliers, or shipping to downstream customers. However, finding co-location patterns of customers and suppliers may reflect, rather than have been created by, geographic concentration. Causality is not uni-directional (or the direction may be that firms located in clusters, perhaps because of some natural advantage of the location, then proceed to buy and sell locally); so it is not sufficient to demonstrate that a cluster exists and then to deduce that agglomeration economies are the cause of colocation. This is often ignored in empirical work dealing with spillovers.

Co-location is also likely if there is a large, common pool of labour. This maximises the 'fit' between productivity levels in firms and workers, since it allows (at lower cost) for labour sorting. It also facilitates workers acquiring industry-specific skills (human capital), since the risk of not being able to appropriate the returns from training are lower where there a large(r) number of potential employers. Again, reverse causality is a possibility because firms may be hiring the same type of workers, because they happen to already be located in the same geographical area.

Lastly, firms may co-locate to obtain knowledge spillovers that occur when similar firms engage in, say, R\&D to solve similar or related problems. Physical proximity (and density) speeds the flow of ideas, especially when a significant part of intangible knowledge is often tacit (and therefore difficult to codify), and (social) networks tend to be strong. ${ }^{17}$

These three types of MAR-spillovers are based on different types of externalities, according to how they are mediated. Scitovsky (1954) and then Griliches (1979, 1992) distinguished between pecuniary (also called vertical, welfare or rent) spillovers which are based on market transactions, and non-pecuniary (also called horizontal, knowledge and technological) spillovers which are based on non-market interactions usually involving the sharing of knowledge and expertise. The first type usually depends on buyer-seller linkages and occurs because quality improvements in inputs and outputs are not fully appropriated and thus are not entirely reflected in the price of such goods and services. Thus recipients of these welfare enhancing externalities experience a cost-reduction and a subsequent rent gain. As explained by Koo (2005), such pecuniary externalities are associated with the first two major sources of agglomeration linked to MAR-spillovers: intermediate inputs and labour pools. They are also emphasised in new economic geography models, where 'blackbox' technological externalities are generally omitted (Neary, 2001, p. 550) and where instead the "...intensity (of pecuniary externalities) can be traced back to the values of fundamental microeconomic parameters such as the intensity of returns to scale, the strength of firms' market power, the level of barriers to goods and factor mobility" (Ottaviano and Thisse, 2001). In contrast, technological spillovers are disembodied from new goods and services (and this direct input-output linkages) and instead arise when firms in proximity share a general pool of knowledge, which can shift their (and 
thus the economy's) production possibility frontier (unlike pecuniary spillovers which usually help firms to move to/along the existing production frontier). Such externalities tend to be emphasised in the new industrial geography (cf. Barnes and Gertler, 1999) and new growth theory literatures (e.g. Romer, 1990; Black and Henderson, 1999), and they are associated with the third major source of agglomeration linked to MAR-spillovers: knowledge spillovers.

MAR-spillovers are often associated in the literature with two major types of agglomeration (cf. Audretsch, et. al., 2007): industrial districts and industry agglomerations. The former arises from the co-location of SME's that typically arose from the break-up of large integrated firms within an industry, with each SME producing different niche-products that originally were produced by a single firm. There are frequent exchanges of personnel between firms in the supply-chain, and they often share innovations; while local infrastructure is tailored to the needs of the industry (including education, financial services, technical support, and trade associations). Industrial districts are generally less common than industry agglomerations, which are also dominated by one industry but there still remain parts of the original vertically integrated companies, with other parts outsourced. Such low vertical integration in the industry necessitates close coordination and cooperation between the original firms and suppliers (e.g. to facilitate just-in-time production and R\&D spending especially on process innovations). ${ }^{18}$ More recently, a third type of agglomeration has come to prominence: that of the concept of an anchor firm(s) that is large and heavily engaged in $R \& D$ and which confers significant externalities on smaller innovative firms (cf. Agrawal and Cockburn, 2003; Feldman, 2003). The idea originated from the real estate economics literature where a large department store in a shopping mall creates externalities for other shops; in the wider context anchor firms attract human capital and specialised suppliers and in general enhance the regional innovations system.

As well as MAR-spillovers leading to specialisation and thus industrial districts and agglomerations, spillovers can also result from urbanisation externalities due to the size and heterogeneity (or diversity) of an (urban) agglomeration. These are labelled Jacobian spillovers (Jacobs, 1970, 1986), and they result when different industries benefit from economies of scope (rather than scale). A greater range of activities (e.g. R\&D, business services, cultural and lifestyle amenities, and the overall quality of the public infrastructure - cf Florida, 2002; Glaeser et. al., 2001) leads to inter-industry spillovers. (Larger) firms - and especially multinationals - tend to locate their head office management and R\&D functions in urban agglomerations. Thus these agglomerations not only tend to generate more product innovations, but there is more likelihood of spin-offs and/or start-ups, which creates a thicker entrepreneurial culture. ${ }^{19}$

Since MAR-spillovers are associated more with specialisation, while Jacobian spillovers are linked to diversity, it is often assumed that distinguishing between the two types will be difficult in empirical work (if both are present), unless micro-level data is available which allows different firms in different industries to be tested for different types of spillover effects. Some aggregate studies that have compared the two types generally seem to favour urbanisation economies (e.g. Glaeser et. al., 1992; Quigley, 1998; van Stel and Nieuwenhuijsen, 2004; van Oort, 2007); some favour localisation economies (Drennan, 2002; Acs, et. al. 2002) but the evidence is not extensive enough to be compelling. ${ }^{20}$ Others have avoided the issue by arguing that different stages of a product's life-cycle is likely to be associated with, first, diversity 
and urbanisation externalities (in formative and innovative stages when the firm is more likely to locate in a larger city), followed by specialisation and benefiting from localisation externalities (in more mature phases when settled on a product line or process). In more recent years, micro-level studies have been conducted that allow for both MAR- and Jacobian spillovers thus providing a clearer picture; for example, Henderson (2003) used the U.S. Longitudinal Respondents Database to estimate plant-level panel data production functions, finding evidence in favour of MARspillovers but little support for the existence of Jacobian externalities. Baldwin et. al. (2008) have undertaken a similar exercise using Canadian data, finding overall support for both types of spillovers although there were different effects depending on the industrial grouping considered. Autant-Bernard and Massard (2004) look at French plants and come to similar conclusion to Baldwin et. al. (op. cit.), while van der Panne (2004) used data on the number of innovators in Dutch regions with the results generally supporting MAR-spillovers, and thus specialisation. In summary, Cheshire and Malecki (2004) suggest that " ... both specialisation and diversity are important - specialisation in industries other than the most traditional so that lock-in does not occur - and diversity of firm size as well as across industrial sectors so that new ideas and technologies are able to enter the regional mainstream" (p. 258).

Having defined in some detail what the literature means by agglomeration economies, we now turn to a discussion of the importance of knowledge to regional growth. We shall then consider regional 'innovation systems', underpinned by the importance of tacit knowledge and the notion of the 'learning region', where the role of spillovers is extended even further.

\section{(c) Regional growth in a knowledge-based economy}

The importance and role of knowledge assets in determining competitiveness, productivity, and ultimately output growth is a strongly recurring theme in the (spatial and non-spatial) literature. A useful distinction can be made between knowledge that is already internal to the firm (through learning-by-doing that draws on existing knowledge and human capital, built-up through R\&D and similar investments) and knowledge gained externally (some of which is through market transactions, such as spending on extramural R\&D, and some of which is gained through spillovers). Geographic boundaries are also important since spillovers are the result of co-location and/or spillovers affects are limited by distance. The need for close proximity is mainly predicated on the notion that a significant part of knowledge that affects economic growth is tacit, and such knowledge does not move readily from place to place as it is embedded in individuals and firms and the organisational systems of different places (Gertler, 2003). ${ }^{21}$

The use of intangible assets (which can be defined as knowledge embodied in intellectual assets, such as R\&D and proprietary know-how, intellectual property, workforce skills, world-class supply networks and brands) is recognized as a key (some say the key) driver of enterprise performance and thus ultimately aggregate productivity and growth. A related concept that is closely linked to intangible assets is absorptive capacity (simply defined as the ability of enterprises to internalize and use external knowledge). This concept has also been the subject of much debate in terms of what it actually covers and how it can be measured. 
Building intangible assets requires that firms understand how to create new knowledge from the resources they possess. Thus to understand how firms create intangible assets requires us to look briefly at the 'resource-based' theory of the firm. The latter holds that a firm can generate higher "Ricardian" rents ${ }^{22}$ from the utilisation of firm specific assets which cannot be replicated by other firms. The thrust of the argument is based on the established assumption (Hymer 1976) that 'better' firms possess non-tangible productive assets that they are able to exploit to give them a competitive advantage. Such a resource-based and organisational capabilities approach to the firm (e.g., Barney, 1991; Kogut and Zander, 1996; Teece et. al. 1997) is concerned with how resources, skills and capabilities (i.e. tangible and non-tangible assets) are generated, accumulated and deployed. The literature in this area concentrates on the firm defined as bundles of various assets (Penrose, 1959). But in addition to tangible assets which operate through relatively clearly defined markets, there are intangible assets (Griliches, 1981), or firm-specific capabilities (Teece and Pisano, 1998; Pavitt, 1984) which largely define the dynamic capabilities that then characterise the firm's competitive advantage.

Essentially Teece and his associates argue that the firms' dynamic capabilities are the sub-set of its competences and capabilities that allow the firm to create new products and processes and to respond to changing market conditions; they are the core of its competitiveness. Fundamentally, proponents of the resource-based view of the firm (like Teece) argue that such competencies and capabilities by their very nature cannot be bought; they can only be built by the firm - they therefore cannot easily be transferred or built-up outside the firm. ${ }^{23}$ This in part comes from the key role that learning plays both in enabling the firm to align its resources, competencies and capabilities, and in allowing the firm to internalise outside information into knowledge; and the way the firm learns is not acquired but it is determined by its unique 'routines', culture and its current position (stock of knowledge).

Thus, processes of knowledge generation and acquisition within the firm (i.e. internal knowledge generation) are essentially organisational learning processes (Reuber and Fisher, 1997; Autio, et. al., 2000). Although firms could develop and acquire much of the knowledge internally (through their own resources and routines), few (and especially SMEs) virtually possess all the inputs required for successful and sustainable (technological) development. Therefore, the fulfilment of firms' knowledge requirements necessitates the use of external sources to acquire and internalise knowledge (Rosenkopf and Nerkar 2001; Almeida et. al., 2003 set out the main external sources of knowledge available to firms).

Knowledge and learning can be expected to have a fundamental impact on growth in that firms must apprehend, share, and assimilate new knowledge in order to compete and grow in markets in which they have little or no previous experience (Autio, et. al. 2000). Prior related knowledge confers an ability to recognize the value of new information, assimilate it, and apply it to commercial ends. These abilities collectively constitute what we call a firm's "absorptive capacity". ${ }^{24}$ This is not a new concept in the regional literature; e.g. Verspagen and Schoenmakers (2004) found that knowledge is more easily absorbed in regions that already have a relatively higher productivity level and a large stock of knowledge. ${ }^{25}$

A crucial element here is that unless firms have sufficient absorptive capacity, they will not be able to fully internalise the benefits of any spillovers, agglomeration economies, or benefit from technology transfers. Evidence shows that firms who 
generate more useful information internally are more likely to combine their internal and external sourcing strategies. For example, Cassiman and Veugelers (1998) found that internal sourcing complimented the use of extramural R\&D, providing support to the absorptive capacity theory; i.e., for a firm to take advantage of knowledge acquired externally, it needs to develop internally to facilitate a smooth assimilation of the external expertise. Indeed, Veugelers (1997) found that "cooperation in R\&D has no significant effect on own $R \& D$ unless the firms have an own R\&D infrastructure, in which case cooperation stimulates internal R\&D expenditures. These results support the idea that indeed absorptive capacity is necessary to be able to capitalise on the complementarities between internal and external know-how" (p. 312). Bonte (2004) found higher returns for West German manufacturing when the share of external (contracted-out) R\&D rose, but there is general recognition that there are likely to be significant constraints on outsourcing R\&D linked to issues surrounding absorptive capacity - if too much of a capability is outsourced it may be difficult for a firm to (re-)integrate it into the firm's operations. As Mowery and Rosenberg (1989) concluded: "co-operative research programs alone are insufficient....more is needed, specifically the development of sufficient expertise within these firms to utilize the results of externally performed research".

Much of the discussion in this sub-section has been on how firms acquire and use knowledge, or what might be termed the 'learning firm'. The use of knowledge assets leads to innovation, and the ability to innovate is a primary driver of growth (Aghion and Howitt, 1992). Moreover, a firm's internal R\&D and use of other intangible assets is no longer sufficient to achieve technological competitiveness and/or to innovate. Thus to undertake successful $R \& D$ and be innovative, the firm is dependent on external sources for knowledge. In addition, regions show differential capabilities to absorb and translate available knowledge into (endogenous) economic growth. It is argued that the empirical evidence shows the "ability to adapt new technologies depends on the institutional infrastructure, education, geography, and resources devoted to R\&D" (Maurseth and Verspagen, 1999, p.152). This therefore leads on to the importance of the regional innovation system in facilitating firms to acquire external knowledge; i.e. we now turn to the concept of the 'learning region' (cf. Cooke and Morgan, 1998; Oughton et. al.., 2002; Cooke et. al.., 2003; Howells, 2002; Asheim and Gertler 2005).

\section{(d) Innovation systems}

The above analysis stressed the importance to firms of (tacit) knowledge gained externally, and that location matters since spillovers are the result of co-location and/or spillovers effects are limited by distance. The 'innovation systems' approach goes further in that it argues that all aspects of the regional system affect the ability to exploit external knowledge. It is not sufficient to just consider how MAR- and Jacobian spillovers impact on firms within a region; among other factors the institutional environment acts directly as a generator of collective synergies and externalities (cf. Dosi et. al., 1988; Freeman and Soete, 1997). Indeed Cooke (1997) goes further:

"A regional innovation system is typically ... composed of economic (e.g. firms, private research institutes), institutional (e.g. education institutions, government departments, chambers of commerce), technological (e.g. 
technology transfer agencies) and social sub-systems, which interact continuously with each other and operate as a system. Change in one subsystem induces change in other sub-systems and, therefore, the adaptation process of different dimensions of the system to one another becomes dynamic.... The focus is thus on the relationships and flows between the various actors and parts of the innovation system" (p. 362)

So whereas earlier work on agglomeration economies was focused on spillovers between firms, the systems approach emphasises the (face-to-face) connections between individuals. Knowledge diffusion primarily emerges by means of social contacts, and social networks can play a key role. ${ }^{26}$ As argued by Putnam (2000), this results in social capital, based on relationships of trust in the reciprocity of shared knowledge, which increases the flow of knowledge within the social network and boosts "localized knowledge spillovers" (Feldman, 1999). The emphasis is on "untraded interdependencies" (Storper, 1997) between economic agents, including firms that are 'deep' or 'thick' in some regions, 'thin' or 'shallow' in others (Lawson, 1999).

One of the founders of the 'innovations systems' approach states that it is not a theory of innovation but a "focussing device" for factors relevant to the process of innovation (Edquist, 1997). Most of the evidence supporting the existence and importance of such systems is case-study based and thus the lessons are less easy to generalise. Attempts to test its applicability more widely (e.g. Crescenzi, 2005) are usually forced to use general, inadequate proxies and the results do not necessarily support or reject the relevance of the approach. ${ }^{27}$ In addition, and from a policy perspective, it is difficult to see which - indeed whether - policies can "create" such territorially bounded systems, partly because the concept is too broad and complex, and partly because not enough is known, or understood, about the nature of "untraded interdependencies".

Bergek et. al. (2008) recognise these limitations of the technological innovations system' (TIS) approach and so they suggest the need to concentrate on the key processes which have "... a direct and immediate impact on the development, diffusion and use of new technologies, i.e. the overall function of the TIS" (p.409). Accordingly they start with defining the TIS (comprising actors, networks and institutions) before looking at the processes involved in the interplay between components of the system, and assessing whether these processes are functioning well or not (and thus what can be done to make the TIS work better). To an economist, the approach taken by Bergek and her collaborators is not about modelling (and therefore testing any hypotheses for) what is a complex system involving a large number of interactions (processes) between its components; rather the approach remains descriptive and subjective. It is also more relevant to mapping out new/emergent technologies, and has little to say about the existing production part of the system (see Markard and Truffer, 2008) and thus how overall increases in productivity (through efficiency gains) are generated in the spatial economy. Another important issue concerns the delineation of the system where: "...there is no one correct choice - the starting point depends on the aim of the study and the interests of the involved stakeholders (e.g. researchers or policy makers)" (Bergek et. al., op. cit. p. 411). Thus delineation "... is based on the assumption that system boundaries are "somehow out there', i.e. that a system has certain characteristics, which may be empirically identified in a specific innovation field" (Markard and Truffer, op. cit., p. 601). Markard and Truffer and others (e.g. Cheshire and Malecki, 2004; Edquist, 2005) also 
make the point that activities in the system can only be performed by actors (such as firms), not by institutions or networks (the former are passive and set incentives; the latter facilitate the execution of activities).

While a consideration of the strengths and weaknesses of any regional innovation system might seem appealing, it is reminiscent of the literature on 'growth poles' that developed in the 1950's and 1960's (see Perroux, 1955; Kuklinski, 1973). Richardson (1978) reviewed this literature stating:

"Of all the spatial concepts developed within the last two decades, none has proved more elusive yet aroused more interest than that of growth poles... unfortunately it has never lived up to its promise. Despite a voluminous, interpretive literature, it remains cloudy and ill-defined" (p.164)

Without wishing to do the concept of regional innovation systems too much injustice, historical parallels will surely apply unless research is forthcoming that is of more relevance to spatial policy-makers.

\section{The Future...}

\section{(a) Micro-level analysis and firm heterogeneity}

Aggregate models of growth (e.g. the Kaldor-Dixon-Thirlwall and New Economic Geography models) provide important and relevant insights into those factors that drive regional development. Thus the importance of, inter alia, exporting, endogenous technical change, agglomeration economies and spillovers, are demonstrated. But such models are by their nature too aggregate for empirical testing, especially in their ability to discriminate between which factors are most important in determining productivity, competitiveness, and growth, as well as which are exogenous to the region and therefore amenable to policy intervention.

Moreover, such models fail to recognise that plants and firms are heterogeneous, and "... this obscures the individual processes that generate industrial or regional productivity change and the different mechanisms that influence those processes" (Rigby and Essletzbichler, 2000). In every region, there are plants that operate at or close to the production possibility frontier, and every region has a 'long tail' of underperforming plants (Harris, 2001, Figure 2). These productivity distributions also display a high degree of inertia, and the position that plants occupy in the distribution is highly persistent over time.

In addition, the need to understand how plants/firms break down barriers to growth, such as those associated with undertaking $\mathrm{R} \& \mathrm{D}$, innovation, and exporting, requires the use of micro-level spatial data. In particular, we need to be able to investigate and understand in much greater depth the factors that determine which plants experience productivity improvements, whether this leads to increased market shares (and thus improvements in 'industry-mix'), as well as the scale and causes of plant entry and exit (i.e. what Schumpeter called 'creative destruction' - see, for example, Boekerman and Miliranta, 2007, for Finland; and Harris and Robinson, 2005, for UK regions). The scale of plant entry in a region is linked to the amount of entrepreneurial 
capital available, and this is linked to overall regional competitiveness and growth (Audretsch and Keilbach, 2005). All of this suggests that more research is needed at the micro-level that considers the role of intangible assets, as part of the way that the enterprise utilises knowledge to provide a competitive advantage and thus achieve a higher growth path.

Furthermore, we need to be able to measure spillovers more exactly, and their relative importance in determining plant-level productivity; this will also require the measurement of absorptive capacity, since it has been argued above that unless plants have sufficient absorptive capacity, they will not be able to fully internalise the benefits of any spillovers, agglomeration economies, or technology transfers.

The potential importance of the clustering of plants/firms (in terms of supply-chain linkages; technology transfers; innovation and learning and thus the existence of innovation systems) is largely ignored in the literature that looks to measure the importance of, say, spillovers from FDI (cf. De Propris and Driffield, 2006). ${ }^{28}$ And yet policy-makers offer major financial incentives to encourage the inward location of FDI. Typically in the past this has been to address the symptoms of regional disparities, such as unemployment, rather than to encourage the geographical concentration of production facilities linked to global markets and benefiting from FDI spillover effects (see Taylor and Wren, 1997; Wren, 2005, shows how FDI accounted for about $10 \%$ of RSA offers between 1990-2003 but 50\% of total assistance offered). Studies for the UK (e.g. Devereux, Griffith and Simpson, 2007) have generally found that FDI tends to locate near to other foreign-owned plants in the same industry (while RSA has little impact on the location decision per se) ${ }^{29}$; a recent study for France (Crozet, et. al., 2004) found broadly similar results. In addition De Propris and Driffield, op. cit., showed that "firms in clusters gain significantly from local FDI, both within the industry of the domestic firm, and across other industries in the region. In the non-cluster case, however, there are no such spillovers, merely (a) negative 'crowding out' effect". Clearly, significant further work needs to be done using appropriate micro-based datasets to consider the issue of clustering within and across different spatial areas.

\section{(b) Knowledge production functions}

Undertaking this research agenda requires both access to relevant data, and appropriate methods. With regard to micro-level (panel) data at the plant level, within the UK researchers can access the Annual Respondent's Database (ARD), the Business Enterprise Research and Development (BERD) data, and the Community Innovation Survey (CIS) data. The latter has recently been used to construct a measure of absorptive capacity (Harris and Li, 2008), while the use of the ARD has resulted in a number of studies already (see Harris and Trainor, 2005; Duranton and Overman, 2006). Other countries have similar access to plant- or firm-level microdata (some more extensive, some less), as evidenced by the range of studies and countries covered in recent meetings of the Comparative Analysis of Enterprise (micro) Data (CAED) conferences (e.g. CAED, 2008). ${ }^{30}$

It is possible to link UK micro-level data (at the establishment level) comprising financial information from the ARD and the BERD (currently) for the years 19962006. Thus it is possible to construct a merged BERD-ARD dataset that can be used to estimate the link between the R\&D capital stock and productivity, using either a 
'knowledge production function' approach (Wieser, 2005) and/or based on the 'two faces of R\&D' approach (cf. Griffith et. al., 2004; Cameron et. al., 2005) which explicitly allows for lagging regions to benefit from technology transfers and thus 'catch-up' with the leading region. The types of models that can be considered are set out in Harris et. al. (2006, par 2.63ff.). ${ }^{31}$

Thus, in future research it should be possible to estimate for different industries and (sub-) regions of the UK both knowledge production functions and the 'two faces of R\&D' model, using appropriate panel data techniques (such as the dynamic GMM approaches proposed by Arellano and Bond, 1998, which allows for endogeneity and panel effects). Sample-selection issues (which are particularly important when testing policy interventions) can also be handled if appropriate identifying instruments are available (see Harris, 2005, for a discussion). Industry and spatial interactions can be incorporated explicitly as spillover impacts, whereby the aggregate outcomes of activities by plants/firms in different industries and spatial areas are included directly as determinants of output at the plant/firm level. ${ }^{32}$

Finally, there is a need to research the interaction between productivity and exporting at the spatial level. Firms that export tend to have the highest productivity levels, i.e., they derive significant benefits from internationalisation, ${ }^{33}$ while the literature generally shows that increased $\mathrm{R} \& \mathrm{D}$, linked to greater absorptive capacity, is also associated with greater exposure to internationalisation (as $\mathrm{R} \& \mathrm{D} /$ absorptive capacity reduce entry barriers into international markets). Harris and Li (2005 and 2006) review the literature at the national level, while Harris and Li (2008) provide microlevel results for the UK; at the spatial level see, for example, Johansson and Karlsson (2007) for Swedish regions. Within the extant spatial literature, research on agglomerations/clusters has "... focused on the internal characteristics and mechanisms in those places and diverted attention from the necessary distinct, even global, linkages that competitive places require" (Cheshire and Malecki, 2004, p. 259). Access to panel data on which plants have internationalised, and linking these data to the ARD, will extend the knowledge production function approach further, and allow testing of the productivity enhancing effects of exporting (as well as R\&D).

\section{Summary}

This paper considers past and present models, which highlight the importance of both demand- and supply-side factors in determining related to regional growth. The neoclassical model of spatial convergence is probably the least relevant of all the models considered, because of its restrictive underlying assumptions and the results generally obtained from empirical testing which mostly do not support 'catch-up' growth. Even when this model is extended to include convergence 'clubs' and spatial dependence, the results obtained by researchers change little. And yet this model is probably the most popular, given the number of studies that continue to be published.

Kaldorian models - emphasising balance-of-payments constraints, cumulative causation, quality enhancing endogenous technical change, and divergent growth paths - provide useful and still relevant theoretical guidance to understanding the determinants of regional growth. The main drawback is that a lack of inter-regional trade data makes these models almost untestable. New Economic Geography models 
have many similar attributes to Kaldorian models, although they stress the importance of transport costs and agglomeration economies and to this extent are more 'spatial' in character. However, they too suffer from data constraints (as well as multiple equilibria complexities) that make them less useful for empirical work. However, the conceptual framework that is available from both Kaldorian and NEG models does provide the regional economist with theoretical insights against which any applied (micro-based) work can be assessed.

The importance of knowledge assets and the 'resource-based' theory of the firm provides important insights into the role of intangible assets, and the role of absorptive capacity. The latter is agreed to be crucially important if spillovers are to be internalised by firms. Thus differences across regions in levels of absorptive capacity are deemed to be of particular importance in understanding differences in firm performance.

Following on from the idea of the 'learning firm', the concept of the 'learning region' was then discussed in relation to regional innovation systems. While this approach provides important insights to the type of ideal cluster that regions might aspire to, it was argued that their complexity limits their usefulness (especially for empirical work and building up evidence-based knowledge on what determines growth across different regions).

Finally, it was argued that the emerging research agenda on regional productivity, competitiveness and growth is likely to benefit from concentrating more on understanding the causes and consequences of firm heterogeneity, and its implications for spatial analysis. Thus we need to understand how plants/firms break down barriers to growth; and the factors that (exogenously) determine which plants experience productivity improvements, as well as the scale and causes of plant entry and exit This suggests that more research is needed at the micro-level that considers the role of intangible assets, as part of the way that the enterprise utilises knowledge to provide a competitive advantage and thus achieve a higher growth path. The use of micro-data on plants can also help us to measure absorptive capacity and spillovers more exactly, and their relative importance in determining plant-level productivity. Finally, further work needs to be done using appropriate micro-based datasets to consider the issue of clustering within and across different spatial areas. 


\section{References}

Abreu, M. et. al., (2005) A Meta-Analysis of $\beta$-Convergence: the Legendary $2 \%$, Journal of Economic Surveys, 19, 3, 389-420.

Acs, Z.J. et. al (2002) High-technology employment and R\&D in cities: Heterogeneity vs specialization. Annals of Regional Science, 36: 373-386.

Aghion, P. and Howitt, P. (1992) A model of growth through creative destruction, Econometrica, 60, pp.323-351.

Agrawal, A. and I. Cockburn (2003) The Anchor Tenant Hypothesis: Exploring the Role of Large, Local, R\&D-intensive Firms in Regional Innovation Systems, International Journal of Industrial Organization, 21, 1227-1253.

Almeida, P., Dokko, G., and Rosenkopf, L. (2003) Startup Size and the Mechanisms of External Learning: Increasing Opportunity and Decreasing Ability? Research Policy, 32(2), 301-315.

Arellano, M. and Bond, S.R. (1998) Dynamic Panel Data Estimation using DPD98 for GAUSS: A Guide for Users. available at http://www.american.edu/academic.depts/cas/econ/gaussres/regress/dpd/dpd9 $\underline{\text { 8.pdf }}$

Armstrong, H.W. and J. Taylor (2000) Regional Economics and Policy, Oxford: Blackwell.

Arrow, K.J. (1962) The economic implications of learning by doing, Review of Economic Studies, 29, 155-173.

Ashcroft, B. et. al. (1994) The Regional Dimension of Takeover Activity in the United Kingdom, Scottish Journal of Political Economy 41, 163-175

Asheim, B. and M.S. Gertler (2005), The Geography of Innovation: Regional Innovation Systems, in J. Fagerberg, D. Mowery and R. Nelson, eds, The Oxford Handbook of Innovation. Oxford: Oxford University Press, 291-317.

Audretsch, D, B. and Keilbach, M, K. (2005) Entrepreneurship capital and regional growth, The Annals of Regional Science, 39 pp. 457-469.

Audretsch, D.B. et. al. (2007) It's all in Marshall: The Impact of External Economies on Regional Dynamics, CESIFO Working Paper No. 2094, Category 5: Fiscal Policy, Macroeconomics and Growth

Autant-Bernard, C. and N. Massard (2004) Pecuniary and Knowledge Externalities as Agglomeration Forces: Empirical Evidence from Individual French Data, mimeo.

Autio, E., Sapienza, H., and Almeida, J. (2000) Effect of Age at Entry, Knowledge Intensity, and Imitability on International Growth. Academy of Management Journal, 43, 909-924.

Baldwin, R. et. al. (2003) Economic Geography and Public Policy, Princeton, NJ: Princeton University Press.

Baldwin, R.E and P. Martin (2004) Agglomeration and regional growth, in: J. V. Henderson \& J. F. Thisse (ed.), Handbook of Regional and Urban Economics, 2671-2711, Elsevier. 
Baldwin, R.E. and Okubo, T. (2005) Heterogeneous firms, agglomeration and economic geography: spatial selection and sorting, Journal of Economic Geography 6 (2006) pp.323-346.

Baldwin, J.R. et. al. (2008) Agglomeration and the Geography of Localization Economies in Canada, Regional Studies, 42.1, 117-132.

Barnes, T.J. and M.S. Gertler (1999) The New Industrial Geography: Regions, Regulations and Institutions, Routledge, London.

Barney, J. (1991) Firm Resources and Sustained Competitive Advantage. Journal of Management, 17(1), 99-120.Barro, R.J. and Sala-i-Martin, X. (1995) Economic Growth, MIT Press, Cambridge, MA.

Barro, R.J. and X. Sala-i-Martin (1995) Economic Growth. New York: McGraw-Hill.

Bergek, A. et. al. (2008) Analyzing the Functional Dynamics of Technological Innovation Systems: A Scheme of Analysis, Research Policy, 37, 407-429.

Bessant et. al. (2005) External Knowledge. A review of the literature addressing the role of external knowledge and expertise at key stages of business growth and development. AIM (http://www.aimresearch.org/publications/externalknowledge.pdf).

Beugelsdijk, S. (2007) The Regional Environment and a Firm's Innovative Performance: A Plea for a Multilevel Interactionist Approach, Economic Geography, 83, 181-199.

Black, D. and V. Henderson (1999) A Theory of Urban Growth, Journal of Political Economy, 107, 252-84.

Böckerman, P. and M. Maliranta (2007) The Micro-level Dynamics of Regional Productivity Growth: The Source of Divergence in Finland, Regional Science and Urban Economics, 37, 165-182.

Bonte, W (2004) Innovation and employment growth in industrial clusters: evidence from aeronautical firms in Germany, International Journal of the Economics of Business, 11(3), 259-278.

Bottazzi, L. and Peri, G. (2003) Innovation and spillovers in regions: evidence from European patent data, European Economic Review, 47, pp687-710.

Breau, S. and D. Rigby (2008) Participation in Export Markets and Productivity of Plants in Los Angeles, 1987-1997, Economic Geography, 84, 27-50.

Cabrer-Borrás, B. and G. Serrano-Domingo (2007) Innovation and R\&D Spillover Effects in Spanish Regions: A Spatial Approach, Research Policy, 36, 13571371 .

CAED (2008) Conference, 2008, Budapest, Hungary, May 22-24, 2008. (http://www.upjohninstitute.org/caed/Program20080506.pdf).

Cameron, G. et. al. (2005) Technology Transfer, R\&D, Trade and Productivity Growth', European Economic Review, 49, 3, 775-807, 2005

Cassiman, B. and Veugulers, R. (1998) Complementarity Between Technology Make and Buy in Innovation Strategies: Evidence from Belgium Manufacturing Firms, Department of Economics and Business, Universitat Pompeu Fabra

Cheshire, P.C. and Malecki, E.J. (2004) Growth, development, and innovation: A look backward and forward, Regional Science, 83, pp. 249-267.

Coe, D.T. and Helpman, E. (1995) International R\&D spillovers, European Economic Review, 39, pp. 859-887. 
Cohen, W.M. and Levinthal, D.A. (1989) Innovation and Learning: the Two Faces of R\&D. The Economic Journal, 99, 569-596.Cooke, P. (1997) Regions in a global market: the experiences of Wales and Baden-Württemberg, Review of International Political Economy 4:2 Summer 1997, pp349-381.

Cooke, P. (1997) Regions in a Global Market: the Experience of Wales and BadenWurttemberg, Review of International Political Economy, 4, 349-381.

Cooke, P. and K. Morgan (1998) The Associational Economy, OUP, London.

Cooke, P. et. al. (2003) 'The Golden Thread of Innovation' and Northern Ireland's Evolving Regional Innovation System, Regional Studies, 37(4), 365-379.

Corrado, L. et. al. (2005) Identifying and Interpreting Regional Convergence Clusters across Europe, The Economic Journal, 115, pp. c133-c160.

Crescenzi, R. (2005) Innovation and Regional Growth in the Enlarged Europe: The Role of Local Innovative Capabilities, Peripherality, and Education, Growth and Change, 36:2, pp.471-507.

Crozet, M. et.al. (2004) How do firms agglomerate? A study of FDI in France, Regional Science and Urban Economics, 34(1), 27-54

Cuadrado-Roura, J.R. (2001) Regional convergence in the European Union: from hypothesis to the actual trends. Annals of Regional Science, 35, pp.333-356.

De Groot, H.L.F. et. al. (2007) Agglomeration, Innovation and Regional Development, Tinbergen Institute Discussion Paper 079/3.

De Propris, L. and N. Driffield (2006) The importance of clusters for spillovers from foreign direct investment and technology sourcing, Cambridge Journal of Economics, 30(2), 277-291.

Devereux, M.P. et. al. (2007) Firm location decisions, regional grants and agglomeration externalities, Journal of Public Economics, 91(3-4), 413-435.

Dixon, R. and Thirlwall, A.P. (1975) A model of regional growth rate differences on Kaldorian lines, Oxford Economic Papers, 27(2), pp. 201-214.

Dosi, G. et. al. (1988) Technological change and economic theory. London:Pinter.

Drennan, M.P. (2002) The information economy and American cities. Johns Hopkins University Press, Baltimore.

Duranton, G. and Overman, H. (2006) Exploring the Detailed Location of UK Manufacturing Industries using Microgeographic Data, CEPR Discussion Paper No 5858.

Edquist, C. (1997) Systems of innovation approaches: Their emergence and characteristics. In: Edquist, C. (ed) Systems of innovation: Technologies, institutions and organizations. Pinter, London

Edquist, C. (2005) Systems of Innovation: Perspectives and Challenges, in Fagerberg, J., Mowery, D.C. and R.R. Nelson (eds.) The Oxford Handbook of Innovation, OUP, New York, 181-208.

Ellison, G. et. al. (2007) What Causes Industry Agglomeration? Evidence from Coagglomeration Patterns, NBER Working Paper Series, Working Paper 13068.

Engle, R.F. and D.F. Hendry (1993) Testing super exogeneity and invariance in regression models, Journal of Econometrics, 56, 119-139.

Engle, R.F., Hendry, D.F. and J.-F. Richard (1983) Exogeneity, Econometrica, 51, 277-304. 
Favero, C.A. (2001) Applied Macroeconometrics, Oxford University Press, Oxford.

Feldman, M.P. (1999) The New Economics of Innovation, Spillovers and Agglomeration: A Review of Empirical Studies, Economics of Innovation and New Technology, 8, 5-25.

Feldman, M. (2003) The Locational Dynamics of the US Biotechnology Industry: Knowledge Externalities and the Anchor Hypothesis, Industry and Innovation, 10, 311-328.

Fischer, M.M. and Sturbeck, C. (2006) Pan-European regional income growth and club-convergence: insights from a spatial econometric perspective, Annals of Regional Science, 40, pp.693-721.

Florida, R. (2002) The rise of the creative class and how its transforming work, leisure community and everyday life. Basic Books, New York.

Freeman, C. and Soete, L. (1997) The economics of industrial innovation, Cambridge, MA: MIT Press.

Garnsey, E.W. and Cannon-Brookes, A. (1993) The 'Cambridge Phenomenon' revisited: aggregate change among Cambridge high-technology companies since 1985, Entrepreneurship and Regional Development 5, 179-207.

Gertler ,M.S. (2003) Tacit knowledge and the economic geography of context, or the undefined tacitness of being (there). Journal of Economic Geography, 3, pp75-99.

Getis, A and J.K. Ord (1992) The Analysis of Spatial Association by Use of Distance Statistics, Geographical Analysis, 24, 189-206

Glaeser, E.L. et. al. (1992) Growth in Cities, Journal of Political Economy, 100(1), pp126-152.

Glaeser, E. et. al. (2001) Consumer City, Journal of Economic Geography, 1, pp. $27-$ 50.

Gong, G. and W. Keller (2003) Convergence and Polarization in Global Income Levels: A Review of Recent Results on the Role of International Technology Diffusion, Research Policy, 32, 1055-1079.

Gottardi, G. (1996) Technology strategies, innovation with R\&D and the creation of knowledge within industrial districts, Journal of Industry Studies, 3, pp. 119134.

Greenaway, D. and Kneller, R. (2007) Firm Heterogeneity, Exporting and Foreign Direct Investment, The Economic Journal, Vol. 117, pp. F134-F161.

Griffith, R., Redding, S. and van Reenen, J. (2004) Mapping the Two Faces of R\&D: Productivity Growth in a Panel of OECD Industries, Review of Economics and Statistics, 86, 883-895.

Griliches, Z. (1979) Issues in Assessing the Contribution of Research and Development to Productivity Slowdown, Bell Journal of Economics, 10, 92116.

Griliches, Z. (1981) Market Value, R\&D and Patents. Economics Letters, 7(2), 183187.Griliches, 1996

Griliches, Z. (1990) Patent Statistics as Economic Indicators: A Survey, Journal of Economic Literature, 28, pp.1661-1707.

Griliches, Z. (1992) The Search for R\&D Spillovers, Scandinavian Journal of Economics, 94, 29-47. 
Harris, R.I.D. (1988) Market Structure and External Control in the Regional Economies of Great Britain, Scottish Journal of Political Economy, 35, 33460.

Harris, R.I.D. (2001) Comparing Regional Technical Efficiency in UK Manufacturing Plants: The Case of Northern Ireland 1974-1995, Regional Studies, 35, 519354

Harris, R.I.D. (2005) Economics of the Workplace: Special Issue, Scottish Journal of Political Economy, 52, 323-343

Harris, R.I.D. and Lau, E. (1998) Verdorn's Law and Increasing Returns to Scale in the UK Regions, 1968-91: Some New Estimates Based on the Cointegration Approach, Oxford Economic Papers, 50, pp.201-219.

Harris, R.I.D and M. Trainor (1999) Manufacturing Industries in the UK: Was There Convergence During the 1968-1992 Period?, Scottish Journal of Political Economy, 46, 552-569

Harris, R.I.D and R. Sollis (2003) Applied Time Series Modelling and Forecasting, Wiley.

Harris, R.I.D and M. Trainor (2005) Plant-level Analysis Using the ARD: Another Look at Gibrat's Law, Scottish Journal of Political Economy, 52, 492-518

Harris R.I.D. and C. Robinson (2005) Impact of Regional Selective Assistance on Sources of Productivity Growth: Plant-level Evidence from UK Manufacturing, 1990-98, Regional Studies, 39, 751-765

Harris, R.I.D., and Q.C. Li (2005). Review of the literature: the role of international trade and investment in business growth and development. (UKTI, London)

Harris, R.I.D et. al. (2006) Assessing the Case for a Higher Rate of R\&D Tax Credit in Northern Ireland, Report to ERINI, http://www.cppr.ac.uk/media/media 4313 en.pdf.

Harris, R.I.D., Li, Q.C. (2006) Causal Links Between International Trade and Investment and Innovation: A Review of Theory and Evidence (UKTI, London)

Harris, R.I.D. and Q.C. Li (2008) Exporting, R\&D and Absorptive Capacity in UK Establishments, Oxford Economic Papers, forthcoming.

Henderson V. (2003) Marshall's Scale Economies, Journal of Urban Economics 53, $1-28$

Hendry, D.F. (1995) Dynamic Econometrics, Oxford University Press, Oxford.

Henley, A. (2005) On Regional Growth Convergence in Great Britain, Regional Studies, 39(9), pp.1245-1260.

Hirshmann, A.O. (1958) The Strategy of Economic Development

HMSO (1963) Belfast Regional Survey and Plan: Recommendations and Conclusions, Belfast (Matthew's Report)

Howells, J. (2002) Tacit Knowledge, Innovation and Economic Geography, Urban Studies, 39: 871-884.

Hunt Report (1969). The Intermediate Areas. Report of a Committee under the Chairmanship of Sir Joseph Hunt. London: H.M. Stationery Office. Cmnd 3798

Hymer, S.H. (1976) The International Operations of National Firms: a Study of Foreign Direct Investment, Cambridge: MA. 
Jacobs, J. (1970) The Economy of Cities, Vintage, New York, NY.

Jacobs, J. (1986) Cities and the Wealth of Nations. Vintage, New York, NY.

Jaffe, A.B. (1986) Technological Opportunities and Spillovers of R\&D: evidence from firms patents, profits and market value. American Economic Review 76, 984-1001.

Jaffe, AB. et. al. (1993) Geographic Localization of knowledge spillovers as evidenced by patent citations. Quarterly Journal of Economics, 108, pp577598.

Johansson, S. and C. Karlsson (2007) R\&D Accessibility and Regional Export Diversity, Annals of Regional Science, 41, 501-523.

Kaldor, N. (1970) The case for regional policies, Scottish Journal of Political Economy, 17(4) pp.337-348.

Kersley B, et. al. (2006) Inside the Workplace: Findings from the 2004 Workplace Employment Relations Survey, Routledge, London.

Kogut, B. and Zander, U. (1996) What Do Firms Do? Coordination, Identity, and Learning. Organization Science, 7(5), 502-523.

Koo, J. (2005) Technological Spillovers, Agglomeration, and Regional Economic Development, Journal of Planning Literature, 20, 99-115.

Krugman, P. (1980) Scale Economies Product Differentiation and the Patterns of Trade, American Economic Review, 70, 950-959

Krugman, P. (1991) Geography and Trade, Cambridge, MA: MIT Press.

Krugman, P.R. and Venables, A.J. (1990) Integration and the competitiveness of peripheral industry. Centre for Economic Policy Research Discussion Paper Series 363.

Krugman, P. and Venables, A. (1995) Globalization and the inequality of nations. Quarterly Journal of Economics, 110, pp. 857-880.

Kuklinski, A. (1973) Growth Poles and Growth Centres in Regional Planning, Mouton \& Co, The Hague.

Lawson, C. (1999) Towards a Competence Theory of the Region, Cambridge Journal of Economics, 23, pp. 151-166.

Lehto, E. (2007) Regional Impacts of Research and Development on Productivity, Regional Studies 41: 623-638.

Lopez-Bazo, E. et. al. (1999) Regional economic dynamics and convergence in the European Union. Annals of Regional Science, 33(3), pp.343-370.

Lucas, R (1976) Econometric Policy Evaluation: A Critique. Carnegie-Rochester Conference Series on Public Policy 1: 19-46

Magrini, S. (1999) The evolution of income disparities among the regions of the European Union. Regional Science and Urban Economics 29, pp257-281.

Markard, J. and B. Truffer (2008) Technological Innovation Systems and the Multilevel Perspective: Towards an Integrated Framework, Research Policy, 37, 596-615.

Markusen, A. (1996) Sticky places in Slippery Space: A Typology of Industrial Districts, Economic Geography, 72, pp.293-313.

Marshall, A. (1890) Principles of Economics, Macmillan, London. 
Maskell, P. (1992) Learning in the village economy of Denmark: the role of institutions and policy in sustaining competitiveness. In Braczyk, H.J., Cooke, P. and Heidenreich, M. (eds) Regional Innovation Systems: The Role of Governance in a Globalized World, pp. 190-213. Taylor \& Francis, London.

Maurseth, P.B. and Verspagen, B. (1999) Europe: One or several systems of innovation? An analysis based on patent citations. In The economic challenge for Europe, ed. J. Fagerberg, P. Guerrieri, and B. Verspagnen, pp18-43. Cheltenham: Edward Elgar.

McCann, P. (2001) Urban and Regional Economics, OUP.

McCombie, J.S.L. (1988) A Synoptic View of Regional Growth and Unemployment: II-The Post-Keynesian Theory, Urban Studies, 25, 399-417

McCombie, S.L. and de Ridder, J.R. (1984) The Verdoorn Law Controversy: Some New Empirical Evidence Using US State Data, Oxford Economic Papers, 36, pp.268-284.

McCombie, J.S.L. and Roberts, M. (2007) Returns to Scale and Regional Growth: The Static-Dynamic Verdoorn Law Paradox Revisited, Journal of Regional Science, 47:2, pp.179-208.

Melitz, M. (2003) The Impact of Trade on Intra-industry Reallocations and Aggregate Industry Productivity, Econometrica, 71, pp.1965-1725.

Mowery, D.C. and N. Rosenberg (1989) Technology and the Pursuit of Economic Growth, CUP.

Myrdal, G. (1957) Economic Theory and the Underdeveloped Regions, London: Duckworth.

Neary, P. (2001) Of Hype and Hyperbolas: Introducing the New Economic Geography, Journal of Economic Literature, 39, 536-561.

Niebuhr, A. (2000) Räuniliche Wachstumszusanimenhänge - empirische Befunde für Deutschland. Discussion Paper No. 84. HWWA, Hamburg.

Niosi, J. and M. Zhegu (2005) Aerospace Clusters: Local or Global Knowledge Spillovers?, Industry and Innovation, 12, 5-29.

Ó hUallacháin, B. (2007) Regional Growth in a Knowledge-based Economy, International Regional Science Review, 30, 3, 221-248.

Ó hUallacháin, B. and T.F. Leslie (2007) Rethinking the Regional Knowledge Production Function, Journal of Economic Geography, 7, 737-752.

Ottaviano, G.I.P, and J-F. Thisse (2001) On Economic Geography in Economic Theory: Increasing Returns and Pecuniary Externalities, Journal of Economic Geography, 1, 153-179.

Oughton, C., Landabaso, M. and Morgan, K. (2002) The Regional Innovation Paradox: Innovation Policy and Industrial Policy, Journal of Technology Transfer, 27(2): 97-110.

Pavitt, K. (1984) Patterns of Technical Change: Towards a Taxonomy and a Theory. Research Policy, 13(6), 343-373.

Penrose, E. (1959) The Theory of the Growth of the Firm, Oxford: OUP.

Peri, G. (2005) Determinants of Knowledge Flows and Their Effect on Innovation, The Review of Economics and Statistics, 87(2), 308-322

Perroux, F. cois. (1955) Not su la Notion de Pole de Croissance, Economique Appliquee, 7, pp.307-320. 
Piore, M. and Sabel, C. (1984) the Second Industrial Divide. Possibilities for Prosperity. New York, NY: Basic Books Inc.

Porter, M. (1998) Clusters and the New Economics of Competition, Harvard Business Review, Nov-Dec., 77-90.

Puga, D. (2002) European regional policies in light of the recent location theories, Journal of Economic Geography, 2(4), pp.372-406.

Putnam, R. (2000) Bowling Alone: The Collapse and Revival of American Community, New York: Simon and Schuster.

Quigley, J.J.M. (1998) Urban diversity and economic growth. Journal of Economic Perspectives, 12, pp.127-138.

Reuber, A.R. and Fischer, E. (1997) The Influence of the Management Team's International Experiences on the Internationalization Behaviour of SMEs. Journal of International Business Studies, 28(4), 807-825.

Rey, S.J. and Montouri, B.D. (1999) US Regional Income Convergence: A Spatial Econometric Perspective. Regional Studies, 33, pp143-156.

Richardson, H.W. (1973) Regional Growth Theory, London: Macmillan.

Richardson, H. W. (1978) Regional \& Urban Economics. Penquin Books

Rigby, D.L. and Essletzbichler, J. (2000) Impacts of Industry Mix, Technological Change, Selection and Plant Entry/Exit on Regional Productivity Growth, Regional Studies, 34, pp.333-342.

Roberts, M. (2007) The Conditional Convergence Properties of Simple Kaldorian Growth Models, International Review of Applied Economics, 21:5, pp.619632.

Rodriguez-Pose, A. (1999) Innovation prone and innovation averse societies: Economic Performance in Europe. Growth and Change, 30, pp75-105.

Romer, P.M. (1986) Increasing returns and long-run growth, Journal of Political Economy, 94(5) pp.1002-1037.

Romer, P.M. (1990) Endogenous Technological Change, Journal of Political Economy, 98, S71-102.

Rosenkopf, L. and Nerkar, A. (2001) Beyond Local Search: Boundary-Spanning, Exploration, and Impact in the Optical Disc Industry. Strategic Management Journal, 22(4), 287-306.

Saglio, J. (1992) Localized Industrial Systems in France: a particular type of industrial system. In Storper, M. \& Scott, A.J. (eds) Pathways to industrialization and Regional Development, pp.230-253. Routledge, London.

Saxenian, A.L. (1994) Regional Advantage, Culture and Competition in Silicon Valley and Route 128. Harvard University Press, Cambridge, MA.

Scitovsky, T. (1954) Two Concepts of External Economies, Journal of Political Economy, 62, 143-51.

Storper, M. (1997) The Regional World: Territorial Development in a Global Economy. New York: Guilford Press.

Taylor, J. and C. Wren (1997) UK Regional Policy: an Evaluation. Regional Studies, $31,835-48$.

Teece, D.J. (1996) Firm Organization, Industrial Structure, and Technological Innovation. Journal of Economic Behavior \& Organization, 31(2), 192-224. 
Teece, D.J., Pisano, G., and Shuen, A. (1997) Dynamic Capabilities and Strategic Management. Strategic Management Journal, 18(7), 509-533.

Teece, D.J. and Pisano, G. (1998) The Dynamic Capabilities of Firms: an Introduction. In: Dosi, G., Teece, D.J., and Chytry, J.(eds.) Technology, Organization and Competitiveness. Perspectives on Industrial and Corporate Change, 193-214. Oxford: Oxford University Press.

Thirlwall, A.P. (1980) Regional Problems are 'Balance-of-Payments' Problems. Regional Studies, 14, 419-25.

Thorton, P.H. and Flynne, K.H. (2003) Entrepreneurship, networks and geographies, In: Acs, Z., Audretsch, D. (eds) The International Handbook of Entrepreneurship. Kluwer Academic Press, Dordrecht.

van der Panne, G. (2004) Agglomeration Externalities: Marshall versus Jacobs, Journal of Evolutionary Economics, 14, 593-604.

van Oort, F.G. (2007) Spatial and Sectoral Composition Effects of Agglomeration Economies in the Netherlands, Papers in Regional Science, 86, 5-30.

van Stel, A.J. and Nieuwenhuijsen, H.R.(2004) Knowledge Spillovers and Economic Growth: An Analysis Using Data of Dutch Regions in the Period 1987-1995, Regional Studies, 38:4, pp. 393-407.

Vega-Jutado, J. et. al. (2008) The Effect of External and Internal Factors on Firms' Product Innovation, Research Policy, 37, 616-632.

Verspagen, B., Schoenmakers, W. (2004). The spatial dimension of patenting by multinational firms in Europe. Journal of Economic Geography, 4, 23-42

Veugelers, R. (1997) Internal R\&D Expenditure and External Technology Sourcing, Research Policy, 26, 303-15.

Wieser, R. (2005) Research And Development Productivity And Spillovers: Empirical Evidence At The Firm Level, Journal of Economic Surveys, 19(4), $587-621$

Wren, C. (2005) Regional Grants: Are They Worth It? Fiscal Studies, 26(2), 245-275. 


\section{Appendix 1}

For policy purposes particularly (but also in more general terms of trying to understand the processes underlying growth) we are looking to establish (causal) linkages between variables. Thus, for example, suppose the policy-maker is interested in the factors that determine a variable $y_{t}$ (e.g. the level of output in a particular spatial economy), where for simplicity we assume that $\mathrm{x}_{\mathrm{t}}$ captures all known determinants:

$$
\mathrm{y}_{\mathrm{t}}=\gamma \mathrm{x}_{\mathrm{t}}+\alpha \mathrm{y}_{\mathrm{t}-1}+\mathrm{u}_{\mathrm{t}}
$$

For simplicity, assume $x_{\mathrm{t}}$ is given by:

$$
\mathrm{x}_{\mathrm{t}}=\xi_{\mathrm{t}-1}+\varepsilon_{\mathrm{t}}
$$

If $u_{\mathrm{t}}$ and $\varepsilon_{\mathrm{t}}$ are not correlated, we can state that $\mathrm{E}\left(u_{\mathrm{t}} \varepsilon_{\mathrm{s}}\right)=0$ for all $t$ and $s$, and then it is possible to treat $x_{\mathrm{t}}$ as if it were fixed for the purposes of estimating (A.1). That is, $x_{\mathrm{t}}$ is independent of $u_{\mathrm{t}}$ and we can treat it as (strongly) exogenous in terms of (A.1) with $x_{\mathrm{t}}$ being said to (Granger-) cause $y_{\mathrm{t}}$. ${ }^{34}$ Therefore, for strong exogeneity to exist $x_{\mathrm{t}}$ must not be Granger-caused by $y_{\mathrm{t}}$, and this leads onto the concept of weak exogeneity.

Note, if (A.2) is reformulated as:

$$
\mathrm{x}_{\mathrm{t}}=\xi_{1} \mathrm{x}_{\mathrm{t}-1}+\xi_{2} \mathrm{y}_{\mathrm{t}-1}+\varepsilon_{\mathrm{t}}
$$

then $\mathrm{E}\left(x_{\mathrm{t}} u_{\mathrm{t}}\right)=0$ is retained but since past values of $y_{\mathrm{t}}$ now determine $x_{\mathrm{t}}$, the latter can only be considered weakly exogenous in the conditional model (A.1). ${ }^{35}$

Weak exogeneity is a necessary condition for super exogeneity, but the latter also requires that the conditional model is structurally invariant; i.e., changes in the distribution of the marginal model for $x_{t}$ (equation (A.2) or (A.3)) do not affect the parameters in (A.1). In particular, if there are regime shifts in $x_{\mathrm{t}}$ then these must be invariant to $(\gamma)$ in (A.1).

It is useful to provide a brief example of testing for super exogeneity in order to make the concept clearer. ${ }^{36}$ Assuming that known institutional (e.g. policy) and historical shifts (shocks) can be identified that affected $x_{t}$, it should be possible to construct a dummy variable (e.g. $\mathrm{POL}_{\mathrm{t}}$ ) that augments (A.3):

$$
\mathrm{x}_{\mathrm{t}}=\xi_{1} \mathrm{x}_{\mathrm{t}-1}+\xi_{2} \mathrm{y}_{\mathrm{t}-1}+\xi_{3} \mathrm{POL}_{\mathrm{t}}+\varepsilon_{\mathrm{t}}
$$

Assuming that the estimate of $\hat{\xi}_{3}$ is (highly) significant in determining $x_{\mathrm{t}}$, then super exogeneity can be tested by including POL $\mathrm{t}_{\mathrm{t}}$ in the conditional model (A.1) and if this dummy is significant then super exogeneity is rejected. ${ }^{37}$

The importance of these three concepts of exogeneity are discussed in Favero (2001, p.146): (i) if we are primarily interested in obtaining an unbiased estimate of the $\gamma$ parameter in (A.1), then if $x_{\mathrm{t}}$ is weakly exogenous we only need to estimate (A.1) and not also (A.3); (ii) if we wish to dynamically simulate $y_{\mathrm{t}}$, and $x_{\mathrm{t}}$ is strongly exogenous, again we only need to estimate (A.1) and not also (A.3); and (iii) if the objective of modelling $y_{\mathrm{t}}$ is for econometric policy evaluation, we only need to estimate the conditional model (A.1) if $x_{\mathrm{t}}$ has the property of being super exogenous. The latter is a 
necessary condition to avoid the Lucas Critique (see Lucas, 1976). For example, suppose $y_{\mathrm{t}}$ is a policy variable of government (e.g. the level of output in a region) and $x_{\mathrm{t}}$ is a variable that government seeks to positively influence through the operation of some policy instrument(s) (e.g. the provision of grants or subsidies), then $x_{\mathrm{t}}$ must be super exogenous to avoid the Lucas Critique. Otherwise, setting $x_{\mathrm{t}}$ would change the policy model (the parameters of A.1), and the policy outcome would not be what the model (A.1) had predicted. ${ }^{38}$

\section{NOTES}

${ }^{1}$ Appendix 1 discusses the exogeneity concept and what is needed to avoid the Lucas Critique.

${ }^{2}$ Note, TFP - the growth in output not due to the growth in capital and labour - in practice covers not only outward shifts in an economy's PPF (due to technical progress) but also movements towards the best-practice PFF (due to increases in efficiency).

${ }^{3}$ To this extent (and referring back to the last footnote), technology diffusion equates to increases in efficiency rather than technical progress per se.

${ }^{4}$ The actual speed-of-convergence is measured as $\mathrm{b}=-\ln (1+\beta) / \mathrm{T}$. This statistic is often used in conjunction with the so-called half-life time it takes to achieve an elimination of $50 \%$ of the gap in the per-capita output levels. Half-life is given by $t_{\text {half-life }}=\ln (2) / b=0.69 b^{-1}$.

${ }^{5}$ Note, $\varepsilon_{\mathrm{i}}$ in equation (3) picks up all other factors determining the convergence process, such as differences in technology. If equation (3) includes other factors that are known to impact on output growth (e.g. differences in human capital), then we have the conditional $\beta$-convergence model.

${ }^{6}$ Evidence for convergence using a time-series approach is even more limited. For example, Harris and Trainor (1999) compared 13 manufacturing industries in each of the standard UK regions with their corresponding industry net output levels in the Greater South East, finding that in only $12 \%$ of cases was there any significant evidence of 'catching-up' (30\% showed equilibrium divergence; $29 \%$ showed there was long-run equilibrium such that there was neither movement apart or closer together; while in $29 \%$ of the pair-wise comparisons the results indicated disequilibrium.

${ }^{7}$ Invoking the 'law of one price' is justified (see McCann, 2001, p. 234) as follows: (i) regions operate in a single currency national area and therefore cannot initiate changes in the rate of exchange; (ii) prices tend to be set in oligopolistic industries which ensure (through Cournot bargaining) relative price stability between competing producers even when costs change; and (iii) the degree to which there is spatial competition and the size of geographical transaction costs are such that nominal prices between regions remain relatively stable over long periods

${ }^{8}$ E.g. $\dot{M}=\Delta M / M$

${ }^{9}$ We are assuming counter-balancing items on the rest of the current account and the capital account are not likely to sustain a trade deficit as they imply a running down of the region's assets. More tenuously, this means we are ignoring higher transfer payments and/or net government consumption as a means of sustaining a long-run trade deficit.

${ }^{10}$ The 2004 Workplace Employment relations Survey (WERS) survey for Great Britain shows that some $41 \%$ of employees work in plants that state that "demand depends heavily on superior quality" (37\% in perhiperal regions and $44 \%$ in central and southern regions) - Kersley et. al. (2006)

${ }^{11}$ The steady-state output growth rate is given by combining equations (6), (8), (11) and (12):

$\dot{Y}=(\theta \dot{a} \dot{Z}) /(\pi-\theta b \dot{Z})$

${ }^{12}$ The model could be made more realistic by treating 'word income' in the export demand equation as an endogenous variable, or at least expanding the term to include intermediate as well as final goods, and thus allowing for interrelationships between regions that take account of spillovers and common shocks - in other words to allow for co-movement in the growth of output across different regions.

${ }^{13}$ Corrado et. al. (2005) use the KPSS test for stationarity (rather than a test against the null of nonstationarity, as set out in equation 4), and it is not clear if a trend was also included in the model. In addition, it might also have been useful (having grouped regions into clubs) to then have used a 
multivariate panel cointegration test to ensure that each 'club' indeed comprised time-series that cointegrated. See Harris and Sollis (2003, Chapter 7) for panel cointegration tests.

${ }^{14}$ Note, patent documents provide a paper trail of knowledge flows (see Jaffe et. al., 1993), thus avoiding to a much greater extent the use of ad hoc proximity measures.

${ }^{15}$ Which is more important - labour or capital mobility - depends on which factor adjusts more quickly to market signals.

${ }^{16}$ Indeed, a recent attempt to integrate Melitz's (2003) model of monopolistic competition and heterogeneous firms into a NEG setting (Baldwin and Okubo, 2005), shows that those firms that are most likely to (re)locate into the 'core' are the most productive firms, while the least attractive find it optimal to stay in the periphery. As shown in their paper “... highly productive firms are systematically subject to greater agglomeration forces and weaker dispersion forces than are less productive firms. Because more productive firms have lower marginal costs, they tend to sell more so that backward and forward linkages operating in the bigger market are systematically more attractive to the most efficient firms. Similarly, these firms' high productivity also means that they are systematically less harmed by the higher degree of local competition in the big market" (p.324).

${ }^{17}$ Such networks will be discussed in greater detail when dealing with 'innovation systems'.

${ }^{18}$ See the example provided by van Stel and Nieuwenhuijsen (2004) with regard to the company Océ (pp. 395-396)

${ }^{19}$ A third approach to agglomeration is the work of Porter (1998) which emphasises inter-firm local competition within his 'diamond' model.

${ }^{20}$ De Groot et. al. (2007) have analysed 31 journal articles which build on the seminal work of Glaeser et. al. (1992) and find a mixed set of results (although perhaps more weight in favour of Jacobian spillovers, which given their emphasis on papers related to city growth may not be surprising).

${ }^{21}$ For evidence and more discussion on spillovers being spatially bounded, see Thorton and Flynne (2003); Bottazzi and Peri (2003); Niebuhr (2000); Henderson (2003); and Baldwin et. al. (2008). Recently, Peri (2005) used patent data for a panel of 113 European and North American regions over 22 years, finding that the externally accessible stock of R\&D had a positive impact on firm innovation but that only about 20 percent of average knowledge is learned outside the region of origin and only 10 percent outside the country of origin. In contrast, Lehto (2007) used R\&D data for Finnish firms and found that only when other firms' $R \& D$ is located in the same sub-region is there any positive spillover effect. On this evidence, R\&D spillovers appear to be (very) localised. However, there are also studies that find stronger support for international knowledge spillovers, rather than localised spillovers. These emphasise transmission through international trade, FDI, international technology transfer, and other forms of internationalisation (e.g. Gong and Keller, 2003; Niosi and Zhegu, 2005; and a recent review by Harris and Li, 2006)

${ }^{22}$ Defined as returns in excess of their opportunity costs, to distinguish them from monopolistic rents when firms restrict output.

${ }^{23}$ As if to emphasise the point about dynamic capabilities, Teece (1996) sets out what he considers the fundamental characteristics of technological development: its uncertainty, path dependency, cumulative nature, irreversibility, technological interrelatedness (with the complementary assets), tacitness of knowledge (organisational routines), and inappropriability (which means that firms' cannot necessarily obtain full property rights over their technology). All of this points to the outcome that technological 'know-how' is 'locked-in' to the firm and future alternatives are path dependent.

${ }^{24}$ Note, absorptive capacity was developed by Cohen and Levinthal (1989) in the context of innovation for which outside sources of knowledge are critical. However the usefulness of the concept extends to all questions relating to the identification, assimilation and application of new, external information (Bessant et. al. 2005)

${ }^{25}$ There is a large and well-established literature on the role of knowledge; e.g. surrounding the work on the 'knowledge production function'. Thus, Griliches (1990) shows that the impact of cumulated general knowledge stocks on the production of new knowledge is positive; the larger the existing stock of knowledge, the fast new knowledge is produced.

${ }^{26}$ This is particularly emphasised in studies of industrial districts (e.g. Piore and Sabel, 1984; Gottardi, 1996; Garnsey and Connon-Brookes, 1993; Saxenian, 1994; Maskell, 1992; Saglio, 1992).

${ }^{27}$ Crescenzi (op. cit.) states: “... the need for a feasible specification of the innovative process, which inevitably implies some simplistic assumptions, must not hide the complexity of the real world as represented by the systems approach". Effectively, he argues that the results need to be seen through the 'lens' of the systems approach, rather than his model providing any evidence for/against it.

${ }^{28}$ Historically, though, regional policy embodied a 'growth centre' strategy in the 1960's (see HMSO, 1963; also Hunt Report, 1969, especially paragraph 443). 


\footnotetext{
${ }^{29}$ Note also Devereux, Griffith and Simpson (2007) have also found that conditioning on industrial concentration, the most geographically concentrated industries appear to be relatively low-tech.

${ }^{30}$ Note, however, that only a small number of studies typically analyse data at the sub-national level.

${ }^{31}$ Recently the use of knowledge production functions has been questioned when analysing innovation at the regional level (Ó hUallacháin and Leslie, 2007). However, the main issue is the appropraiteness of using regional rather than firm- or plant-level data. As stated by Beugelsdijk (2007) “... it is important to test theoertical hypotheses at the level that fits the logic of the argument (p.183), and the the knowldge production function that is at the firm- or plant-level. An example using micor-level data for Spain is Cabrer-Borrás and Serrano-Domingo (2007)

${ }^{32}$ Agglomeration effects due to clustering can also be incorporated explicitly using appropriately constructed variables (see, for example, Harris et. al., 2006; van Oort, 2007). Alternative econometric approaches can be used, such as spatial autocorrelation techniques, to provide further insights into the interdependencies across regions, although the preferred approach (given the discussions above) would be to incorporate spatial interactions through directly measured spillover impacts. Of course, such an approach may not pick up knowledge spillovers but rather "spatially correlated technological opportunities" (Griliches, 1996) since technological (and geographic) proximity is likely to be correlated with exogenous technological (and spatial) opportunity conditions - if new opportunities exogenously arise in a technological (or geographical) area, firms active in that area will all increase their R\&D spending (and improve their productivity assuming a positive $R \& D$ impact on productivity), and this would erroneously show up as a spillover effect. Note, this problem has also been more recently noted by Baldwin and Okubo (2005); if the most efficient firms move to large regions (as their model suggests will happen), "average firm productivity in big regions is higher even if there are negligible agglomeration economies in operation" (p.337) Thus there is a need to consider appropriate econometric methodologies to avoid endogeneity problems.

${ }^{33}$ There is ample evidence for this based on national studies (see Greenaway and Kneller, 2007, for a review); at the sub-national level very little evidence exists (although see Breau and Rigby, 2008).

${ }^{34}$ Equation (A.1) is called a conditional model in that $y_{\mathrm{t}}$ is conditional on $\mathbf{x}_{\mathrm{t}}$ (with $\mathbf{x}_{\mathrm{t}}$ determined by the marginal model given in (A.2)).

${ }^{35}$ That is, $x_{\mathrm{t}}$ still causes $y_{\mathrm{t}}$ but not in the Granger sense because of the lagged values of $y_{\mathrm{t}}$ determining $x_{\mathrm{t}}$. For a review of these concepts of weak and strong exogeneity, together with their full properties, see Engle, Hendry and Richard (1983).

${ }^{36}$ This example is based on Hendry (1995, p. 537). Further discussion of super exogeneity can be found in Favero (2001, p. 146), Hendry (op. cit., p. 172) and Engle and Hendry (1993).

${ }^{37}$ I.e., its exclusion from (A.1) would alter the estimate of $(\gamma)$. Note also, that the residuals $\hat{\varepsilon}_{t}$ from (A.4) should not be a significant determinant of $y_{\mathrm{t}}$ in equation (A.1).

${ }^{38}$ Essentially this is the problem of 'selectivity' in estimating such a model, which is commonly encountered when considering (usually micro-based) policy initiatives by government. If economic agents (e.g. firms) also "know" the model (the policy rule) underlying (A.1) and (A.4), when POL $_{t}$ changes, agents alter their behaviour (the parameters of A.1 change) since they have anticipated the intended impact of government policy. Econometric models that fail to separate out the expectations formulation (in this case the sample selectivity aspects) by economic agents, from the behavioural relationships in the model itself, will then be subject to Lucas's critique.
} 


\section{BERR}

\section{Spatial Economics Research Centre (SERC)}

London School of Economics

Houghton Street

London WC2A 2AE

Tel: 02078523565

Fax: 02079556848

Web: www.spatialeconomics.ac.uk

SERC is an independent research centre funded by the Economic and Social Research Council (ESRC), Department for Business, Enterprise and Regulatory Reform (BERR), the Department for Communities and Local Government (CLG) and the Welsh Assembly Government. 